Revista de Derecho Público: Teoría y Método

\title{
NUESTRO LENGUAJE: EL GIRO LINGÜÍSTICO DEL DERECHO*
}

\section{OUR LANGUAGE: THE LINGUISTIC TURN IN LAW}

\author{
Elisa Moreu Carbonell \\ Profesora Titular de Derecho Administrativo \\ Universidad de Zaragoza
}

RESUMEN: El conocido como "giro lingüístico", método centrado en el análisis del lenguaje y sus hablantes, no podía quedar sin consecuencias para el Derecho, que también es un lenguaje. El método lingüístico proporciona herramientas muy útiles para la ciencia jurídica y permite reflexionar sobre la forma de interpretar y comunicar el Derecho.

PALABRAS CLAVE: Método lingüístico; lenguaje jurídico; claridad; lenguaje jurídico fácil; comunicación jurídica.

ABSTRACT: The phenomenon known as the 'linguistic turn' cannot remain without consequences for law and focuses of law primarily on the relations between language and language users. It provides a new perspective upon the subject that is still an innovation in the legal science. This 'language perspective' has to be taken very seriously as it leads to methodological changes that can transform the law.

KEYWORDS: Linguistic turn; legal language; clarity; plain legal language; accessible legal language; communication.

* Este trabajo ha sido elaborado en el marco del grupo de investigación consolidado ADESTER, financiado por el Gobierno de Aragón, y del proyecto i+D del Ministerio de Ciencia, Innovación y Universidades, "P6C2018-099237-B-I00: Bancos de Conservación y otras medidas de compensación ambiental". 
SUMARIO: 1 . UTILIDAD DEL MÉTODO LINGÜÍSTICO APLICADO AL DERECHO.-2. LA LINGÜÍSTICA DEL DERECHO. 2.1 El Derecho como lenguaje de especialidad. 2.2. Los géneros jurídicos. 2.2.1. Lenguaje normativo: la norma. 2.2.2. Lenguaje judicial: la sentencia. 2.2.3. Lenguaje administrativo: el acto administrativo. 2.2.4. El lenguaje forense: la demanda. 2.3. Lenguaje jurídico oral y no verbal. 2.4. El impacto de la imagen en el lenguaje jurídico. 2.5. Lenguaje jurídico e inteligencia artificial.-3. CECI N'EST PAS UNE PIPE O LA DESNATURALIZACIÓN DEL LENGUAJE JURÍDICO. 3.1. Los límites del lenguaje son los límites del mundo. 3.2. El lenguaje jurídico como herramienta para la dirección de conductas. 3.3. La magia de las palabras del Derecho. 3.3.1. Términos comunes y "semitécnicos". 3.3.2. Tecnicismos. 3.3.2. Latinismos. 3.3.4 Neologismos, extranjerismos. 3.4. La interpretación de las palabras del Derecho. 3.4.1. La tarea hermenéutica del jurista. 3.4.2. El canon literal. 3.5. Modelando los conceptos jurídicos a través del lenguaje: el método conceptual aplicado al Derecho.—4. PRAGMÁTICA DEL DERECHO. 4.1. Los sujetos de la comunicación jurídica. 4.1.1. El destinatario del Derecho. 4.1.2. El emisor del Derecho. 4.2. Un diagnóstico demoledor: el lenguaje jurídico fracasa comunicativamente. 4.3. El derecho a comprender el lenguaje jurídico. 4.3.1. Lenguaje jurídico claro. 4.3.2. Lenguaje jurídico fácil. 4.3.3. Lenguaje jurídico inclusivo. 4.4. Lenguaje jurídico universal.-5. CONCLUSIONES.-6. REFERENCIAS BIBLIOGRÁFICAS

«No son los hechos los que conmueven a los hombres, sino las palabras sobre esos hechos»

(Epicteto).

"Lo reconozco, ciertas palabras me crean problemas"

(Confesiones de una máquina lectora de Wislawa Szymborska).

\section{UTILIDAD DEL MÉTODO LINGÜÍSTICO APLICADO AL DERECHO}

La realidad del jurista es eminentemente lingüística y comunicativa. Los juristas somos gente de letras (ROBLES, 2006: 102), utilizamos palabras para definir nuestro mundo y resolvemos conflictos utilizando el lenguaje. El Derecho no se limita a usar el lenguaje como herramienta para comunicar sus contenidos y describir su propia realidad, sino que se manifiesta lingüísticamente (ROSELLI, 2013: 5), en el sentido de que se expresa a través de textos y actos lingüísticos (normas, sentencias, informes, tratados, contratos, planes, resoluciones administrativas, trabajos científicos, dictámenes). El Derecho es nuestro código de comunicación, que diría HABERMAS (1981), y hasta podría afirmarse que el análisis del lenguaje es lo más afin al derecho ${ }^{1}$.

1 Me gusta cómo lo expresa E. García de Enterría en su prólogo al libro de Luis María CAZORLA, El lenguaje jurídico actual: "[E]l mundo jurídico es un vasto e interminable rumor de palabras y los juristas somos ingenieros de las palabras" (GARCÍA DE ENTERRÍA, 2007: 15). Por su parte, R. de 
Aunque parezca una paradoja, esta indisoluble ligazón entre lenguaje y Derecho explicaría la poca atención que los juristas, en especial los administrativistas, hemos prestado a nuestro bagaje lingüístico que quedaría en tierra de nadie en expresión de MARTÍN DEL BURGO (2000: 6) ${ }^{2}$. Los lingüistas siguen monopolizando los estudios dedicados al lenguaje del Derecho ${ }^{3}$. ¿Acaso los juristas tememos perder el tiempo en algo que consideramos sabido en su elementalidad y generalidad?

Es hora de dar un giro lingüistico al Derecho, incorporando a la ciencia jurídica las herramientas metodológicas del conocido como "giro lingüístico" que conmovió los paradigmas de las ciencias sociales desde los años sesenta del siglo pasado. Estoy convencida de que el método analítico-lingüístico ofrece herramientas útiles para avanzar en la sistematización y hermenéutica de la ciencia jurídica (racionalidad jurídica) y lograr un Derecho más eficaz (racionalidad comunicativa). Dicho con otras palabras: el Derecho es un discurso apto para el análisis lingüístico. Los juristas debemos dirigir nuestro foco de atención hacia el lenguaje, tanto desde una perspectiva lógicaformal (su sintaxis, la gramática, la semántica), como desde una perspectiva empírica y pragmática (el contexto, la comunicación, la narración, la traducción). El método analítico-lingüístico no solo atiende a la forma y la estructura lógica de los textos jurídicos, para conseguir una mayor racionalidad sistemática, sino que permite también comprender la función del lenguaje jurídico en el proceso comunicativo, averiguar el propósito de los distintos actos de comunicación jurídica y su interacción con las actitudes de los sujetos (OLIVECRONA, 1962: 31; LLEDÓ, 1970: 116; ALEXY, 1983; ACERO, BUSTOS y QUESADA, 2001: 23, GÓMEZ BORRÁS, 2005: 136, CARRETERO, 2015: 1; y MARTÍN REBOLLO, 2018: 161) ${ }^{4}$.

Mendizábal en la introducción a Ángel MARTÍN DEL BURGO, en El lenguaje del Derecho, sostiene que "en todo jurista hay agazapado un literato" (DE MENDIZÁBAL, 2000: 1). Y B. Schlink, conocido jurista y escritor alemán, autor de Der Vorleser (El lector), afirma que "la verdad del Derecho también está hecha de palabras y frases, como la verdad de las historias” (WILL, 2015: 61).

2 Por supuesto, hay trabajos excelentes realizados por juristas (García de Enterría, Prieto de Pedro, Sáinz Moreno, Olivencia, Martín del Burgo, Cazorla, Conde) y una estupenda revista dedicada al tema (Llengua i Dret, en http://revistes.eapc.gencat.cat/index.php/rld, que edita desde 1983 la Escola d'Administració Pública de Catalunya). Y grupos de investigación que abordan el lenguaje jurídico, como el que dirige Estrella MONTOLÍO en la UB (Grupo EDAP, Estudios del discurso académico y profesional http://www.ub.edu/edap/), si bien su ámbito de actuación no es exclusivamente jurídico. También Cristina CARRETERO, profesora de la Facultad de Derecho de la Universidad Pontificia de Comillas, se ha especializado en el lenguaje jurídico e imparte docencia en oratoria y redacción jurídica.

La Comisión para la Modernización del Lenguaje Jurídico (CMLJ) elaboró en 2011 un "informe de recomendaciones" acompañado de seis estudios de campo sobre distintos aspectos del lenguaje jurídico, donde reclama una mayor colaboración entre los expertos de distintas disciplinas.

${ }^{3}$ Lo cierto es que ellos tampoco se libran de acusaciones de lenguaje oscuro e inaccesible, como refleja magistralmente BENEDETTI en su microrrelato Lingüistas (1989).

${ }_{4}^{4}$ E. GARCÍA DE ENTERRÍA (1994: 37) recuerda que una de las grandes aportaciones de la revolución francesa a la cultura occidental fue la revolución lingüística, ya que no solo contribuyó a ampliar el repertorio léxico jurídico, sino que ofreció "un discurso enteramente nuevo para explicar las relaciones entre los hombres y su organización social y política como materia del Derecho" Para S. MUNOZZ MACHADO (2017), desde finales del siglo xx se está produciendo una nueva "revolución de las palabras" alimentada por los cambios de concepción de muchos derechos individuales y la emergencia 
Como advierte LORENZANO (2011:70) no se trata, simplemente, de enfatizar la centralidad del lenguaje jurídico, sino de identificar el modo en que el método lingüistico impacta en el jurídico:

- El enfoque lingüistico implica una aproximación puramente lógica que ROBLES (2017:15) denomina teoría formal del Derecho y conecta indirectamente con la semiótica, que estudia los signos que permiten la comunicación. Se dice que el conjunto de las reglas y principios que gobiernan el uso de una lengua viene dado al jurista y que no se pueden alterar. Precisamente por eso, la lingüística ofrece herramientas para mejorar la comprensión y la accesibilidad del Derecho y garantizar la observancia de los principios de seguridad jurídica, certeza y eficacia. Los juristas tenemos que esforzarnos por refinar lógicamente (lingüísticamente) nuestros actos de comunicación jurídica.

- El enfoque de la semántica es útil para determinar el significado del léxico jurídico en la tarea hermenéutica de los juristas. La semántica ayuda a desentrañar el significado de las palabras que forman los textos jurídicos estudiando la codificación de los mensajes y la formación los conceptos jurídicos. Existe también una rama llamémosla histórica o comparativa, que ensaya las transformaciones experimentadas por una lengua a través del tiempo. El jurista puede seguir la pista de otras disciplinas relacionadas con la lingüística que adoptan el lenguaje como objeto de estudio, como la hermenéutica, que es el arte de interpretar el lenguaje, la retórica, la filosofía del lenguaje o la lógica.

- Por último, el enfoque de la pragmática nos permite centrarnos en los hablantes del Derecho, esto es, en el uso del lenguaje jurídico y en los factores (contexto) que condicionan la comunicación (ESCANDELL, 2011: 7). En definitiva, a prestar atención a las variables que determinan la comprensión del lenguaje jurídico, tales como el contexto socio-cultural, la intencionalidad de los sujetos (emisor, destinatario) y el tono del mensaje jurídico.

\section{LA LINGÜÍSTICA DEL DERECHO}

El lenguaje jurídico tiene unos caracteres propios desde el punto de vista lingüístico (gramatical, sintáctico, morfológico, semántico), emplea un vocabulario singular, tiene un estilo y una sintaxis propia y se manifiesta en determinados géneros. Es un lenguaje muy heterogéneo según quién sea su hablante o emisor: el legislador, el juez, la administración, los abogados o el jurista académico. El Derecho es un lenguaje muy formalizado, casi teatral, que suele estar ordenado y controlado. Las modalidades del lenguaje jurídico se canalizan a través de documentos estereotipados que los lingüistas llaman géneros jurídicos: la norma, la sentencia, la demanda o el acto administrativo (BORJA, 2007: 141). También se consideran textos jurídicos lato

de otros nuevos, y las transformaciones del Estado derivadas de la europeización y la globalización de las relaciones económicas y sociales. 
sensu las comunicaciones que los ciudadanos dirigen a las instituciones (solicitudes, formularios) y las relaciones entre particulares con trascendencia jurídica, como los contratos privados. Habitualmente el lenguaje del Derecho se expresa por escrito, aunque también puede recurrir a imágenes o símbolos; puede ser incluso un lenguaje no verbalizado (gestos, silencios) y canalizarse oralmente.

\subsection{El Derecho como lenguaje de especialidad}

Atendiendo a sus características lingüísticas y comunicativas, el Derecho se considera una variante de los lenguajes de especialidad, también denominados lenguajes técnicos o tecnolectos. En definitiva: los juristas hablamos la misma jerga, que es nuestro lenguaje especial ${ }^{5}$. Como todos los lenguajes de especialidad, el jurídico se caracteriza por su funcionalidad: su uso marca identidad sociolingüística y la pertenencia a un grupo o élite, en nuestro caso, el grupo de los juristas (VILCHES, SARMIENTO, 2016: 22).

Aunque no todos los actos comunicativos del Derecho tienen carácter normativo, el lenguaje jurídico es prescriptivo. El emisor formula sus mensajes con carácter regulador, con el objetivo de intervenir en la realidad y conformarla de acuerdo con determinados principios políticos, económicos y sociales (CASTELLÓN, 2006: 189). No es un lenguaje aséptico ni neutro, sino manifestación de las relaciones entre los poderes públicos y los ciudadanos y un reflejo de los principios que inspiran un determinado modelo social (DUARTE, 2002:15). En la comunicación jurídica el emisor suele ocupar una posición de dominio porque interviene el poder público (legislativo, ejecutivo, judicial) con una función básicamente reguladora (normas), aunque también performativa (actos administrativos, sentencias que crean o cambian relaciones jurídicas) o simplemente informativa o interpretativa (trabajos académicos).

En contraste con otros lenguajes especializados como el de la economía o las matemáticas, el Derecho tiene un horizonte amplísimo porque afecta directamente a la esfera de derechos y obligaciones de los ciudadanos (ROSELLI, 2013: 4). El art. 6.1 del Código Civil dispone, como sabemos, que "la ignorancia de las leyes no excusa de su cumplimiento". Sin embargo, la comunicación jurídica no está al alcance del ciudadano medio porque el texto jurídico, y muy especialmente el jurídico-administrativo, impone una distancia insalvable entre el emisor y el receptor. Desde esta perspectiva es un texto que fracasa comunicativamente, porque expulsa de su seno

\footnotetext{
5 Se denominan lenguajes de especialidad (también lenguas profesionales y académicas) las variedades funcionales vinculadas a usos concretos del lenguaje. Se definen como un conjunto de caracteres lingüísticos específicos de un grupo de hablantes dedicados a una actividad determinada, bien sea de carácter profesional, técnico o científico. Por todos, DUARTE (1990: 93), MARTIN et al. (1996: 1), ALCARAZ y HUGUES (2002: 187) y CASTELLÓN (2006: 187). No obstante, no son homogéneos, pues pueden presentar una variación interna de registros y niveles de formalidad. Combinan formas lingüísticas específicas (tratamientos, formas verbales, frases hechas, sufijos, prefijos, latinismos, etc.) con formas generales de la lengua y aparecen habitualmente en textos de comunicación especializada.
} 
al no iniciado y acaba por constituir una especie de jerga arcana que la mayoría de los ciudadanos no comprende ${ }^{6}$. Da la impresión de que el empeño por destacar las particularidades del Derecho como lenguaje de los juristas ha sido una excusa para perpetuar su inmovilismo y aislamiento (CAZORLA, 2007: 26 y 40). Esto explicaría la mala imagen que el ciudadano tiene de la justicia y probablemente la visión del jurista en la literatura y el cine (BIEGER, 2006: 17), o el descrédito de la administración pública (VANDELLI, 2015). Al menos, las burlas de los humoristas y las sátiras de los escritores prueban que el lenguaje jurídico existe (CALVO, 1980: 257), pero “cuánto mejor sería el mundo si se pudiese prescindir de los leguleyos”, en irónica expresión de DÍEZ-PICAZO (2006: XII).

Desde un punto de vista estrictamente formal, el lenguaje jurídico toma como base o se construye sobre el lenguaje común, del que no se puede desligar (ANTELMI, 2008: 89) ${ }^{7}$. Es más: el lenguaje sirve como criterio de corrección de los conceptos jurídicos, de modo que cuanto más cercano esté el concepto jurídico a su significado en el lenguaje común, mejor se garantizará su comprensión (GARCÉS, 2015: 222). El lenguaje jurídico está "forzado a depender de una estructura lingüística generalista" (MARTÍN DEL BURGO, 2000: 27), así que el riesgo de que se produzca un fracaso comunicativo es mayor conforme más apartado esté del lenguaje común.

Por eso, el Derecho no es — no debe serlo— un lenguaje aislado del lenguaje común: el jurista debe adecuarse a las exigencias del lenguaje, y no al revés, sin forzar o desnaturalizar el lenguaje ni recrearse en una jerga técnica alejada del lenguaje común ${ }^{8}$. El voto particular de GONZÁLEZ NAVARRO a la STS 219/2005 (rec. núm. 5267/2000) expresa perfectamente esta idea':

${ }^{6}$ Según el informe de recomendaciones de la CMLJ (2011) y los barómetros de opinión del Consejo General del Poder General, el 82 por 100 de los ciudadanos considera que el lenguaje jurídico es excesivamente complicado y difícil de entender. La percepción negativa se extiende a los estudiantes de las facultades de Derecho. Al parecer, España ocupa el vigesimoquinto lugar (de 28) en la mala percepción que los ciudadanos tienen de la justicia, según se desprende del último informe del Grupo de Estados contra la Corrupción (Greco), del Consejo de Europa (GrecoRC4(2016)1, Fourth Evaluation Round. Corruption prevention in respect of members of parliament, judges and prosecutors, publicado el $10 \mathrm{de}$ octubre de 2016).

7 La STJUE de 4 septiembre 2014 (asunto C-452/13) trata de dilucidar qué debe entenderse por "hora de llegada" a efectos de compensar a los pasajeros de avión por gran retraso en sus vuelos (Reglamento (CE) núm. 261/2004). ¿La hora de llegada viene determinada por el momento en que las ruedas del avión tocan la pista de aterrizaje? ¿La hora de apertura de las puertas del avión? La norma no precisa exactamente este concepto, quizás porque el legislador no imaginó que unos minutos fuesen decisivos para obtener o no la indemnización, así que el TJUE tuvo que dar contenido jurídico a esta expresión.

8 Insistiendo en esta dependencia del lenguaje común, hay autores que evitan calificar al Derecho como lenguaje especial. Para SAINZ MORENO (1976: 98) y GÓMEZ BORRÁS (2005: 99) no existe un lenguaje técnico propio del Derecho - que consideran una utopía—, sino más bien un uso jurídico del lenguaje común y una retórica del Derecho, entendida como dominio de las palabras y los conceptos propios del lenguaje jurídico.

9 Y en otra sentencia anterior, el ponente GONZÁLEZ NAVARRO expresaba así la estrecha vinculación entre lenguaje jurídico y común: "Por supuesto "incongruencia" es un significante al que cada hablante (o cada escribidor) puede dotar del significado que le peta. Pero en el lenguaje jurídico ese significante tiene un significado preciso que es el que permite calificarlo de unidad jurídica. Y desde 


\begin{abstract}
"El lenguaje del derecho es el mismo lenguaje del hombre de la calle" (...) "la peculiaridad semántica del derecho radica en que, salvo unos pocos y, en ocasiones, imprecisos conceptos, el derecho opera con el lenguaje usual (...)La Ley habla, no sólo para juristas, sino para todos los miembros de la comunidad humana que por esas normas han de regirse, para todos y cada uno de sus destinatarios, que son quienes han de cumplirlas, adaptando a ellas sus decisiones con trascendencia jurídica. Y por eso el mensaje, normalmente imperativo, en que la Ley consiste debe ser expresada en el lenguaje que esos destinatarios pueden entender".
\end{abstract}

\title{
2.2. Los géneros jurídicos
}

La aproximación al lenguaje jurídico exige establecer distintos niveles de textos y no tratarlos todos de la misma manera. El lenguaje jurídico se compone, al menos, por cinco subsistemas: el lenguaje normativo (las leyes y demás textos normativos), el lenguaje judicial (los textos decisorios emanados de los jueces y tribunales de justicia); el lenguaje administrativo (integrado por las resoluciones adoptadas por los órganos de las administraciones públicas); el lenguaje de los abogados y otros profesionales del Derecho (que es narrativo y argumentativo en su tarea hermenéutica) y el lenguaje de la autonomía privada (compuesto por los actos jurídicos de los particulares). Estas modalidades del lenguaje jurídico se canalizan a través de documentos estereotipados llamados géneros jurídicos: la norma, la sentencia, la demanda o el acto administrativo.

Nos centraremos ahora en la forma lingüística de los géneros jurídicos más relevantes y al final del trabajo retomaremos su estudio desde una perspectiva pragmática o comunicativa.

\subsubsection{Lenguaje normativo: la norma}

La norma - ley y reglamento— es, en los países de tradición continental, la única forma de creación del Derecho y el emisor de los textos normativos es el legislador lato sensu (parlamentos, gobiernos, administración pública). Solo de forma derivada el Derecho se encuentra en las actuaciones de jueces, en las exposiciones doctrinales y en otros textos jurídicos (LÓPEZ HERNÁNDEZ, 2012: 62).

¿Qué características tienen las normas como enunciados lingüísticos? Su lenguaje es fundamentalmente prescriptivo, porque su función es ordenar conductas. Sin embargo, el lenguaje normativo sufre el impacto de una nueva concepción del ciudadano, como sujeto activo responsable y participativo, y se abren paso nuevos modelos de normas blandas que no ordenan, ni siquiera son vinculantes, sino que aconsejan, sugieren o recomiendan recurriendo al lenguaje indicativo ${ }^{10}$. Dado que está fuer-

luego ese significado no es el que pretende darle el letrado de la parte recurrente" (STS 4281/2000, rec. núm. 1283/1998, FJ. 3).

10 Por ejemplo, la Ordenanza de Circulación de Peatones y Ciclistas de Zaragoza, aprobada en 2009 y afectada por la STSJ de Aragón núm. 85/2012, de 17 febrero, dispone que "se recomienda 
temente condicionada por factores extrajurídicos, la norma tiene también el rasgo lingüístico de la connotación, es decir, una dependencia contextual de cada cultura jurídica. Encontramos incluso ejemplos del lenguaje narrativo, en concreto, en los preámbulos (CALVO, 1996: 73) ${ }^{11}$.

Está claro que la calidad de la norma depende, entre otros factores, del lenguaje jurídico empleado y que el mal uso del lenguaje es un factor de inseguridad jurídica (BERMEJO, 2005). La preocupación por la calidad del lenguaje normativo tiene raíces históricas, pues ya en las Siete Partidas de Alfonso X podemos leer que la escritura de las leyes las "deben hacer hombres sabios y entendidos" y que "ha de ser hecha de muy buenas palabras y muy escogidas" (Ley 9, Título 2, Primera Partida). Bentham identificaba el "arte de legislar" con el dominio del lenguaje por parte del legislador (ZAPATERO, 2004: LII).

El derecho a una legislación de calidad va siendo objeto de reconocimiento expreso, como veremos más adelante, y, en nuestro ámbito, la Ley 39/2015 recoge los principios de buena regulación entre los que no se encuentra la claridad del lenguaje, pero sí la seguridad jurídica y la eficacia, que lo presuponen (art. 129). En relación con ello, podemos recoger aquí dos herramientas básicas para mejorar la calidad lingüística de las normas:

- En primer lugar, las directrices de técnica normativa ${ }^{12}$, aunque lo cierto es que su incumplimiento no tiene consecuencias porque son meras orientaciones que no determinan la nulidad de las normas, como confirma la STSJ de Castilla-La Mancha núm. 7/2016, de 25 de enero (rec. núm. 407/2013, FJ. 3).

- Otra técnica para mejorar el lenguaje normativo son las definiciones contenidas en las propias normas, apartados de carácter metalingüístico que permiten esclarecer

mantener una distancia de seguridad adecuada en los tramos de acera anexos a carriles de aparcamiento o curvas muy pronunciadas" o "es recomendable la utilización del casco protector" (art. 28).

11 Prescindo de deslindar materialmente el "preámbulo" de "exposición de motivos", porque ni las propias normas son coherentes con la opción y porque la discusión no deja de ser puramente nominal: llámense de una u otra forma, son textos introductorios que forman parte de las normas.

La calidad de estos prólogos desde el punto de vista lingüístico es muy desigual. V., con toque crítico, SALVADOR (2004: 638). Un buen ejemplo en la Exposición de Motivos de la Ley de CastillaLa Mancha 6/2004, de 21 de diciembre, para la aplicación al municipio de Albacete del régimen de organización de los municipios de gran población, digno de un folletín de novela rural.

La doctrina alberga dudas sobre el valor normativo de los preámbulos de las normas, con excepción hecha del preámbulo de la Constitución, aunque sí está clara su función interpretativa, especialmente como canon para la interpretación teleológica: véase DÍEZ PICAZO, (1992: 501) y EZQUIAGA (1988: 41). Su función comunicativa se deduce de la jurisprudencia del Tribunal Constitucional; la STC 125/2016, de 7 de julio, niega que el presupuesto habilitante del decreto-ley impugnado haya encontrado reflejo suficiente en su exposición de motivos.

12 En el ámbito estatal, las DTN fueron aprobadas por Acuerdo del Consejo de Ministros de 22 de julio de 2005 e incluyen una serie de pautas lingüísticas (núms. 101 y 102) muy interesantes para conseguir un "lenguaje claro y preciso, de nivel culto, pero accesible" y el "decoro lingüístico de las normas", entre otras: utilizar el léxico común, evitar el uso de extranjerismos, respetar el orden normal de los elementos de la oración, y, en general, adecuar las normas jurídicas a las normas lingüísticas generales de la Real Academia Española. 
a qué se refiere un término jurídico, cada vez más habituales quizás por influjo del Derecho de la UE. DÍEZ SASTRE (2015: 18) recuerda que las definiciones no son per se conceptos jurídicos: simplemente, ofrecen criterios para la interpretación de los términos incluidos en la norma. En relación con la polémica sobre su valor normativo, creo que la respuesta debe ser afirmativa desde el momento en que el legislador obliga a usar un término jurídico en el sentido definido por la norma. Problema bien distinto es el de su coherencia normativa (LÓPEZ HERNÁNDEZ, 2012: 140).

En cualquier caso, el método lingüístico permite afirmar que uno de los problemas de la baja calidad del lenguaje normativo es la dificultad para encontrar al responsable de los textos (SALVADOR, 2004: 631). ¿A quién responsabilizar lingüísticamente de los textos normativos? Ni se sabe, puesto que hay cientos de redactores e intermediarios, y la participación ciudadana incrementa la confusión. Esta realidad podría explicar que la forma lingüística de la norma, que debía ser sencilla y coherente como proclaman las directrices de técnica normativa, sea rebuscada, ambigua y nebulosa.

\subsubsection{Lenguaje judicial: la sentencia}

Otro género jurídico es el que emana del juez y se expresa a través de sentencias. Evidentemente, los jueces no crean Derecho, pero interpretan los textos normativos para aplicarlos al caso concreto objeto de sus decisiones.

¿Cómo es el lenguaje judicial? La sentencia es un texto jurídico informativo, porque resume los datos más relevantes del proceso judicial, y sobre todo argumentativo y directivo, porque comunica y justifica decisiones que afectan directamente a las partes implicadas. Por eso la sentencia constituye uno de los géneros jurídicos más ambiciosos, complejos y de mayor repercusión social (LÓPEZ SAMANIEGO, 2010: 100). Es complejo, porque tiene un carácter intertextual, es decir, reproduce o parafrasea otros textos jurídicos, fundamentalmente normativos (GARCIA ASENSIO, POLANCO, 2012: 196), pero también de otro tipo, tanto escritos (informes periciales), como orales (declaraciones de testigos). Por eso, las sentencias son un instrumento útil para explorar el estilo del lenguaje forense, muy especialmente el oral, porque las manifestaciones de abogados, testigos y otros sujetos implicados en el proceso se reflejan allí, en la parte fáctica de la sentencia ${ }^{13}$. Y con gran repercusión

13 “Una vez más, el juez de instrucción nos ha obsequiado con una decisión sorprendente que ni la ciudadanía ni muchos juristas entendemos. Yo, como una inmensa mayoría de los ciudadanos, no la entiendo (...) Y en el mundo de la justicia yo creo que es muy bueno que la ciudadanía, que partimos de que es un mundo oscuro, que es un mundo esotérico, porque nadie lo entiende nunca, si trasladas a un lenguaje sencillo, muchas de estas cosas tan esotéricas, la gente las entiende porque yo parto del respeto a la ciudadanía. La mayoría de la gente es inteligente y lo entiende y entonces, claro, que unos compañeros hagan estas cosas es muy preocupante. Yo realmente estoy bastante preocupada"son manifestaciones de la magistrada en la STS de 10 abril 2012 (rec. 518/2011). Otra sentencia reconoce las dificultades para entender las alegaciones de la demanda “- con un lenguaje ciertamente oscuro, y de sintaxis difícil de entender y seguir-”" (STSJ Castilla-La Mancha de 1 septiembre 1999, FJ. 6). 
social, porque afecta decisivamente a la esfera vital de sus destinatarios, que son los ciudadanos inmersos en cualquier conflicto jurídico.

La sentencia es, en todo caso, un acto de habla que recurre a la narración y a la argumentación. Sin embargo, sabemos que los juristas —el juez- han prestado mucha más atención a la argumentación jurídica que a la narración, y suelen desconocer las técnicas lingüísticas que definen a una narración eficaz (TARANILLA, YÚFERA, 2012: 165). Más que métodos de interpretación, el juez necesita y utiliza recursos retóricos para convencer (GÓMEZ BORRÁS, 2005: 104).

La estructura básica de las sentencias viene determinada por la ley (art. 248.3 LOPJ), pero eso no evita la enorme desigualdad entre ellas desde el punto de vista narrativo, léxico y estilístico. Tradicionalmente la forma, lenguaje y estilo de cada sentencia ha quedado al gusto de cada juez. La Sala de Gobierno del Tribunal Supremo, mediante acuerdo de 19 de enero de 2016, aprobó un prontuario de estilo para el Tribunal Supremo, elaborado por su gabinete técnico, con reglas muy precisas sobre la estructura de la sentencia, uso de lenguaje no sexista, cuestiones de estilo (mayúsculas y minúsculas, expresiones numéricas, tratamientos, normas de citación, uso de abreviaturas o latinismos), hasta reglas de formato (uso de negrita, subrayado y cursiva).

Aunque el imperativo de calidad se impone a los escritos procesales desde la Carta de los Derechos de los ciudadanos ante la Justicia, aprobada por el pleno del Congreso de los Diputados el 16 de abril de 2002, lo cierto es que los ciudadanos - iy los propios juristas! - tienen serias dificultades para entender los argumentos del juez (MONTOLÍO, 2012: 69). Entre los vicios discursivos que la doctrina identifica como causa de la opacidad del lenguaje judicial destacan errores de las reglas de la sintaxis y la ortografía, la construcción de frases excesivamente largas, con abundancia de oraciones subordinadas, encadenadas mediante engorrosos incisos y gerundios, y, finalmente, problemas de puntuación (ALCARAZ, HUGUES, 2002).

Es momento de explicar aquí el sesgo denominado "dilema de la doble audiencia" estudiado por GIBBONS (2003:15 y 2004:7), que explicaría este desajuste entre la exigencia de claridad para el ciudadano y la opacidad del lenguaje judicial. El juez es consciente de que el principal destinatario de la sentencia es el ciudadano, lego en Derecho. Pero ese mismo juez se debate entre escribir para el ciudadano o escribir para sus colegas de profesión, que también participan en la comunicación judicial porque son sus destinatarios indirectos (los demás jueces, los abogados...). Ante este dilema, el juez suele optar por un discurso especializado, con su léxico propio, su estilo ampuloso y arcaizante y su sintaxis embrollada, por miedo a perder credibilidad profesional. Curiosamente, cuando el juez prevé que la sentencia va a tener una especial repercusión mediática se esfuerza por utilizar un lenguaje más llano y accesible ${ }^{14}$.

14 La transparencia y la publicidad acabarán desfigurando los rasgos tradicionales del lenguaje jurídico (CAZORLA, 2007: 149). Esta afirmación es especialmente clara en los juicios mediáticos con cobertura periodística, cuyo sesgo espectacular y efectista generan una distorsión grave de la comunicación jurídica, acentuándose por ejemplo la personalización de las decisiones judiciales, que no se atribuyen 


\subsubsection{El lenguaje administrativo: el acto administrativo}

De entre todos los géneros del lenguaje jurídico destaca por sus características el lenguaje administrativo, que se manifiesta a través de los textos y actos de habla que emanan de la actividad administrativa y cuyo emisor es una administración pública, sin necesidad de entrar aquí en las difusas fronteras del concepto - funcional, subjetivo, finalista- de administración pública, a la que tantas páginas se han dedicado. Lo definitorio del lenguaje administrativo es su emisor, que se expresa en un contexto muy variado porque la administración tiene la capacidad de actuar en distintos niveles lingüísticos: como creadora de normas, como aplicadora del Derecho, como prestadora de servicios. Normalmente se encauza a través de medios escritos, pero también puede manifestarse de forma oral (actividad informativa), incluso a través de imágenes y símbolos, como las señales de tráfico, o del lenguaje no verbal (gestos de agente de la autoridad), siendo el acto administrativo su manifestación más característica.

En cualquier caso, es evidente que el lenguaje administrativo tiene enorme incidencia en la esfera jurídica de los ciudadanos (CASTELLÓN, 2001: 94).

Desde una perspectiva eminentemente formal, el lenguaje administrativo es un subsistema dentro del lenguaje jurídico. Entre otras particularidades, emplea una terminología propia y es audaz — a veces inconsciente — en la creación de nuevos términos. Abusa de cultismos inútiles, como obrar ("obra en poder de esta administración") o elevar ("elevar un escrito"). Se caracteriza por una tendencia a la repetición sinonímica, el abuso de las siglas, la preferencia por la construcción nominal, demasiadas subordinadas y el uso incorrecto de las iniciales mayúsculas. Estilísticamente es altisonante, arcaico y utiliza fórmulas estereotipadas y redundantes (ALCARAZ, HUGUES, 2002: 23 y PRIETO DE PEDRO, 1991:143 y 2016:134). En definitiva, es un lenguaje poco natural, difícil y oscuro. La admiración por usos lingüísticos de antaño conduce a su petrificación (CAYERO, 2014: 148 y VILCHES, SARMIENTO, 2016: 24).

Desde la perspectiva pragmática, estamos ante un lenguaje fuertemente condicionado por factores extrajurídicos (políticos, económicos) y ello hace que el mecanismo de la connotación adquiera mayor relevancia (CASTELLÓN, 2001: 13). En apariencia, el lenguaje administrativo presenta un alto grado de cortesía reglada, que se manifiesta, por ejemplo, en los tratamientos protocolarios. Se ha dicho que el lenguaje administrativo es conservador, en el sentido de que es un lenguaje autoritario,

\footnotetext{
a la justicia como institución sino al juez en persona (OLIVER-LALANA, 2011: 286), con el riesgo de juicios paralelos impulsados por las redes sociales.

En un interesante estudio sobre la mediática STS (Sala de lo Penal) de 17 de julio de 2008, relativa a los atentados del 11-M en Madrid, LÓPEZ SAMANIEGO (2010: 102) constata que el dilema de la doble audiencia se ha inclinado en favor de los destinatarios no jurídicos, entre ellos: las partes afectadas, la clase política y el conjunto de la sociedad en general, a través de los medios de comunicación. En definitiva, el impacto mediático de la sentencia permite intuir que su redactor invirtió un esfuerzo especial por potenciar la claridad expositiva del texto.
} 
apegado a los formalismos y a las rigideces del aparato burocrático. No obstante, la concepción autoritaria de la administración ha evolucionado y en este aparato lingüístico formalista se han abierto goteras de transparencia, participación y cercanía al ciudadano. Pero ojo porque BAÑO (2016: 497) ha denunciado la vuelta al lenguaje autoritario en las nuevas Leyes 39/2015 y 40/2015.

En relación con ello, otra peculiaridad del lenguaje administrativo es su menor grado de abstracción, su contemplación casuística de la realidad y el descenso a los detalles. Se dice que es un Derecho haciéndose, un Derecho hablándose (HERNÁNDEZ GIL, 1986). Eso condiciona que el lenguaje administrativo sea más disperso y fragmentado, que el nivel de abstracción conceptual sea menor y que los términos empleados estén más próximos al lenguaje natural (ECKARDT, 2000:14). El lenguaje administrativo es mucho más permeable respecto de los valores y estándares sociales: posee, en fin, una mayor "permeabilidad social". El lenguaje administrativo ordena, dispone, fomenta, limita las conductas de los ciudadanos en circunstancias concretas.

Tampoco es indiferente el lenguaje administrativo a la expansión de los medios de comunicación y a la hegemonía de la cultura de masas. Muchas administraciones públicas tienen hoy su propio gabinete de prensa y comunicación y por eso el lenguaje administrativo contemporáneo es más accesible para los medios de comunicación social (CAZORLA, 2007: 152). La administración se ve compelida a adaptar sus mensajes e incluso sus organigramas a los estándares comunicativos de la publicidad comercial (MOREU, 2005).

Por último, el lenguaje administrativo viene determinado por la complejidad de la actividad de las administraciones públicas, que se vale del léxico de otras lenguas de especialidad, como una esponja que absorbe los más variados lenguajes de la economía, las ciencias, las matemáticas, la informática (PRIETO DE PEDRO, 1991: 113). Esto explica, entre otras cosas, que su producción lingüística sea tan abundante y variopinta.

\subsubsection{El lenguaje forense: la demanda y otros escritos procesales}

La profesión elocuente en palabras de MUÑOZ MACHADO (2015: 4) se expresa a través de la demanda y el resto de escritos procesales, sin olvidar, desde luego, la actuación oral del abogado en el teatro de la justicia, del que me ocupo en el epígrafe siguiente.

El abogado es interlocutor esencial de la comunicación jurídica, pues es quien asume la tarea de explicar o traducir los textos judiciales ante los ciudadanos, con fidelidad al interés de sus clientes (FROSINI, 1995: 26). Los abogados son intermediarios entre el juez y sus clientes y por eso importantes libros de estilo jurídico son 
obra de grandes despachos o de los propios colegios ${ }^{15}$. El lenguaje forense tiene también una estructura y estilo propios que han sido objeto de análisis crítico (BAYO, 2000 y GARCÍA ASENSIO, POLANCO, 2012), aunque no tan rígido como el de los textos judiciales. Las polémicas normas sobre extensión máxima de los escritos procesales en el recurso de casación, aprobadas por el Tribunal Supremo el 20 de abril de 2016 (BOE núm. 162, de 06 de julio de 2016) imponen no solo una extensión máxima de los escritos de interposición y contestación (aprox. 25 folios), sino también reglas de formato y estructura, inéditas hasta entonces, aunque parece que se trata de simples orientaciones sin consecuencias procesales (RANGO, 2019).

\subsection{Lenguaje jurídico oral y no verbal}

El lenguaje jurídico es, principalmente, verbal y escrito. Sin embargo, en la comunicación jurídica juegan un papel importantísimo los cauces orales de difusión y también el lenguaje no verbal, en la medida en que constituye una comunicación directa de los emisores del Derecho con los ciudadanos (BAYO, 2011).

(a) El lenguaje jurídico oral ha sido objeto de un estudio de campo específico de la Comisión para la Modernización del Lenguaje Jurídico (2011), tanto en el sector público (servicios de atención al ciudadano), como en juzgados y tribunales. Dicho estudio incluye un análisis bastante pormenorizado del estilo de expresión oral de jueces, abogados y empleados públicos y denuncia vicios a nivel fónico, léxicosemántico y morfosintáctico, además de otros de tipo pragmático, como la falta de cortesía lingüística. En general, se constata el bajo nivel de conocimientos retóricos de los profesionales de la justicia y el escaso dominio en técnicas oratorias y de persuasión.

Paradójicamente, el lenguaje oral es más fácil de adaptar a las necesidades de comprensión y al contexto de sus destinatarios. De hecho, los empleados públicos y otros profesionales que tienen una relación directa con el ciudadano se esfuerzan en conseguir que la persona que está frente a ellos comprenda el mensaje. Pero, si bien la expansión de cauces de comunicación oral en el lenguaje jurídico explicó la relajación de sus exigencias formales en los años ochenta (CALVO, 1980: 259), lo cierto es que ahora las tecnologías van por otros derroteros. El teléfono y la presencialidad están siendo sustituidos por la comunicación virtual y la no presencialidad, que entrañan siempre una comunicación escrita. Así que podríamos decir que la oralidad se pierde por este impacto tecnológico.

15 Por citar dos de ellos, el Libro de estilo Garrigues, Thomson-Reuters, 2006, o el Libro de estilo del Ilustre Colegio de Abogados de Madrid, Marcial Pons, 2007. Además, se editan manuales de redacción y estilo para abogados, normas de "lingüística procesal" y estrategias discursivas, aunque los planes de estudio de las Facultades de Derecho siguen dando la espalda a las asignaturas vinculadas con la mejora del lenguaje jurídico escrito y oral, como denunció BAYO (1996: 56) y la comisión de expertos para la modernización del lenguaje jurídico (CMLJ, 2011). 
(b) El lenguaje jurídico, especialmente el lenguaje judicial, es muy teatral, y, por tanto, emplea formas no verbales de expresión: las togas, las reverencias, el uso de estrados, las rutinas de permanecer de pie o sentados, etc. Ciertas demandas de modernización de la justicia y de la administración pública se orientan indirectamente a flexibilizar el lenguaje jurídico no verbal y "toda esa parafernalia" (MONTOLÍO, 2012: 120).

\subsection{El impacto de la imagen en el lenguaje jurídico}

Las nuevas tecnologías de información y del conocimiento son un factor de modernización del lenguaje jurídico. ¿Cómo cambia el lenguaje jurídico por el impacto de la sociedad visual y tecnificada? El impacto de la cultura visual contemporánea ejerce una notable huella en la interpretación jurídica y en la propia labor del jurista, todavía no suficientemente investigado pero ya con algunas contribuciones relevantes como la del profesor R.K. Sherwin, que constata que el lenguaje jurídico, y muy especialmente el administrativo, evoluciona para adaptarse a una tipología concreta de usuario de los servicios públicos.

La fuerza de la imagen inclina la balanza de la tarea hermenéutica de lo cartesiano a lo intuitivo, como si el dominio de lo virtual condujera a la indiferencia por lo real (SHERWIN, 2011: 179). Lo visual ya no solo se limita a acompañar a la palabra: la imagen es transformativa, tanto cualitativa como cuantitativamente, porque añade emociones y evocaciones. A diferencia del texto escrito, el significado de una imagen puede ser captado de repente y todo a la vez. Se pierde mucho menos tiempo y esfuerzo en absorber una imagen que en leer cien palabras. Para leer este nuevo lenguaje jurídico visual nos sirven los conocimientos de la semiótica (HERITIER, 2014: 25). Por eso, los juristas necesitamos herramientas para desentrańar los códigos de la representación en imágenes. Películas, televisión y videojuegos, como todas las imágenes, tienden a eclipsar a las palabras escritas. Se abre paso una forma nueva de interpretar o entender el lenguaje jurídico, cada vez más visual.

El tradicional verbocentrismo de los textos jurídicos está dando un giro hacia lo visual gracias a la generalización de la informática, y en este proceso han sido pioneros los textos judiciales, por ejemplo las sentencias mercantiles que resuelven pleitos sobre marcas comunitarias, que TARANILLA (2015: 10) llama "jurisprudencia visual ": una nueva dimensión de la práctica jurídica vinculada a competencias requeridas por la era digital.

En relación con la cultura visual, hay otro foco de investigación apenas tratado entre nosotros, como es el lenguaje jurídico que se emplea en los medios de comunicación. El informe de recomendaciones de la Comisión para la Modernización del Lenguaje Jurídico (2011: 22), se ocupa expresamente del tema a partir de un simple dato objetivo: "uno de cuatro ciudadanos tendrá contacto directo con los tribunales alguna vez en su vida", pero "la sociedad se informa y forma su opinión sobre la justicia a través de los medios de comunicación". Como el lenguaje jurídico se adapta mal 
a las exigencias del lenguaje periodístico, se propone que las instituciones promuevan la formación especializada de los periodistas en el buen uso del lenguaje jurídico.

Por otro lado, el reconocimiento del Derecho a comprender y los esfuerzos por conseguir un lenguaje jurídico claro y accesible también dejan su impronta formal en el Derecho, porque la imagen es una herramienta útil para conseguir aquellos objetivos, como retomaré más adelante ${ }^{16}$.

\subsection{Lenguaje jurídico e inteligencia artificial}

El lenguaje jurídico está cada vez más condicionado por la inteligencia artificial basada en algoritmos y análisis de datos (IA). En efecto, la IA se está aplicando en el campo del procesamiento del lenguaje y permite la traducción automática, la realización de resúmenes de textos, la respuesta automática a preguntas o la toma de decisiones jurídicas automatizadas, y ya encontramos numerosas aplicaciones en el ámbito jurídico, también en las administraciones públicas (CERRILLO, 2019 y PONCE, 2019).

Aunque el estudio de la IA y su impacto en el Derecho excede de los objetivos de mi trabajo, sí me gustaría destacar los principales problemas que podrían afectar al lenguaje jurídico:

- El primero de ellos es la transparencia del lenguaje de los algoritmos, esto es, cómo hacer comprensible y accesible este lenguaje (código fuente, análisis de datos, etc.) para los ciudadanos y si debemos permitir la participación ciudadana en su diseño.

- En relación con ello, preocupa también la calidad del lenguaje de la inteligencia artificial. El director de la Real Academia de la Lengua Española, S. MUNOZ MACHADO, decía en una entrevista que "así como hemos educado y regulado con éxito durante trescientos años la lengua de los humanos, queremos también que las máquinas no se desmadren y hablen un buen castellano". Y destacaba como reto de la academia supervisar el lenguaje de las inteligencias artificiales, porque las máquinas "se comen las palabras", en concreto, a través de los correctores ortográficos y las traducciones automáticas ${ }^{17}$.

- El reto básico para el Derecho se asocia con el desarrollo de la neurociencia, que permitirá manipular las neuronas de nuestro cerebro (leer el cerebro) y con ello controlar el libre albedrío de las personas, fundamento de la autonomía de la volun-

16 La Universidad de Stanford (Estados Unidos) fue pionera en la puesta en marcha de un laboratorio de diseño legal (Legal Design Lab, https://law.stanford.edu/organizations/pages/legal-design-lab) integrado por equipos interdisciplinares con el objetivo de crear productos y servicios jurídicos más amables para sus destinatarios (design thinking).

17 Entrevista en el semanario El Cultural (18 de octubre de 2019). 
$\operatorname{tad}^{18}$. Los "neuroderechos" (privacidad mental, identidad personal, libre albedrío, equidad en el aumento cognitivo y protección contra sesgos de la IA), se abren paso para conseguir un estatuto equivalente al de los derechos humanos y algunos Estados, como Chile, proyectan una reforma constitucional para reconocerlos.

\section{CECI N’EST PAS UNE PIPE O LA DESNATURALIZACIÓN DEL LENGUAJE JURÍDICO}

La referencia al conocido cuadro de Magritte que encabeza este epígrafe ilustra uno de los signos de nuestro tiempo como es la proliferación de conceptos inestables, es decir, conceptos de significado ambiguo utilizados conscientemente para confundir al ciudadano.

El lenguaje actúa como límite para la formación y la interpretación de conceptos jurídicos, igual que un molde cuya función sea la de ofrecer cabida a un contenido tan sumamente intangible como el pensamiento abstracto (VERES, 2006: 21). El lenguaje es la herramienta que crea y delimita los conceptos jurídicos, es el código que permite exteriorizar un pensamiento jurídico y, evidentemente, muchos problemas relacionados con los conceptos jurídicos son discusiones puramente terminológicas.

Por eso, la lingüística nos proporciona herramientas para conocer mejor la semántica del lenguaje jurídico. En concreto, la semántica ayuda a desentrañar el significado de las palabras que forman los textos jurídicos, la codificación de los mensajes y la formación de los conceptos jurídicos.

\subsection{Los límites del lenguaje son los límites del mundo}

Recurro a esta frase de L. Wittgenstein porque ilustra bien una de las preocupaciones básicas de los filósofos del lenguaje, que es la vinculación de las palabras y su relación con las cosas. Esta rama de la filosofía está íntimamente conectada con la lingüística, y de hecho la han practicado eminentes lingüistas desde W. von Humboldt a N. Chomsky. Los seres humanos tendemos a atribuir a las palabras un referente empírico ya que el lenguaje sirve para describir y vertebrar nuestro mundo. La división de la realidad sobre la base del lenguaje origina una tendencia a sustantivizar la realidad, en la creencia de que toda palabra designa un objeto empíricamente real, como si las cosas estuvieran adheridas a las palabras ${ }^{19}$.

18 La experimentación en neurociencia demostraría que es posible descodificar el pensamiento, es decir, saber lo que una persona está pensando en cada momento. En estos experimentos, un voluntario observa imágenes que se proyectan para conseguir que cada imagen active zonas de su cerebro. Cada activación funciona como un "concepto" que va permitiendo elaborar un "diccionario" de inteligencia artificial.

19 Los filósofos del lenguaje abordan las relaciones entre lenguaje, pensamiento y realidad e investigan cuál es el origen y la simbolización del lenguaje y sus componentes ontológicos (SEARLE, 1969), 
Las teorías ontológicas propias de la filosofía del lenguaje se han trasvasado al mundo jurídico. Del mismo modo que los filósofos del lenguaje discuten si hay alguna lógica natural en la atribución de palabras que designan la realidad o si se trata de una asociación arbitraria, los filósofos del Derecho se han preocupado por el componente ontológico del lenguaje jurídico. ¿Qué existe detrás de conceptos como derecho, justicia, potestad o gobernanza? ¿Pertenecen a un nivel metafísico o suprasensible o, por el contrario, se refieren a situaciones fácticas concretas? El lenguaje es un elemento básico de la estructura conceptual y la selección del término - la palabra, el significante- es fundamental para la creación de los conceptos jurídicos: "sin palabra adecuada no hay concepto preciso" (DELGADO, 2013: 11 y 14). La filosofía y la psicología conductual han formulado interesantes teorías sobre la vinculación que existe entre el concepto y la palabra (LORENZANO, 2011: 69).

Advierto, en cualquier caso, que no es objeto de mi trabajo la formación de los conceptos jurídicos, tarea a la que DÍEZ SASTRE (2018) ha dedicado un esfuerzo titánico. Mi aproximación a los conceptos jurídicos se limita, como se ha dicho, al análisis lingüístico o formal. Aunque no estoy en condiciones de exponer aquí el impacto que la filosofía del lenguaje ha tenido en el derecho, ni constituye el objeto de este trabajo, sí quiero expresar aquí dos reflexiones:

(a) Primera idea: si el lenguaje nos informa acerca de lo que una sociedad considera importante (MARINA, 1998: 22), los distintos lenguajes jurídicos responden a visiones del mundo también diferentes ${ }^{20}$. Parece claro que para comunicarnos necesitamos algo más que un repertorio de palabras y que una lengua no es sólo una serie de conceptos con sus palabras o etiquetas correspondientes: es un modo de ver el mundo, insustituible e irrepetible, incluso en dominios más complejos o abstractos del lenguaje. Igual que un extraterrestre no podría entender muchas cosas sobre el planeta y los humanos sólo con un diccionario, un lego no puede comprender bien el derecho con un diccionario de términos jurídicos ${ }^{21}$.

pero no se han puesto de acuerdo sobre el componente ontológico del lenguaje ni sobre si la diversidad de lenguajes es una barrera para el conocimiento. Para ilustrar el debate suelen poner el ejemplo de la percepción de los colores. A pesar de que hay lenguas que tienen más vocabulario cromático que otras (por ejemplo, el rumano más que el francés), ninguna lengua tiene palabras para los más de siete millones de matices de color que percibe el ojo humano. Sin embargo, el lenguaje no condiciona la percepción de los colores: se puede percibir el color aunque no se tengan palabras para ese color.

${ }^{20}$ El lingüista de origen judío y profesor de la Universidad de Oxford, G. DEUTSCHER, ofrece una tesis provocadora en su libro El prisma del lenguaje. Cómo las palabras colorean el mundo (2011). El libro actualiza la denominada "corriente culturalista" (cuyos precursores fueron E. Sapir y B.L. Whorf) y reivindica que la realidad está modelada inconscientemente por el lenguaje. Para Deutscher, el lenguaje nos da la forma de la experiencia que imaginamos tener del mundo. Las estructuras de una lengua se explican mejor como producto de la evolución cultural y como respuesta a las exigencias de la comunicación que por el "innatismo" de N. Chomsky. En definitiva, la lengua es el prisma a través del cual vemos el mundo, y lo ilustran estudios empíricos sobre la percepción de los colores o la orientación (DEUTSCHER, 2011: 17).

${ }^{21}$ La aparición del Diccionario del español jurídico, DEJ (2016), que no es el único diccionario jurídico editado en nuestro país, pero sí el primero que se hace con cierto armazón oficial, permite plantear hasta qué punto es factible codificar el lenguaje jurídico en un diccionario y configurarlo como 
(b) Segunda idea: el lenguaje jurídico es, por su especialidad y tecnicismo, una poderosa arma que está al servicio de unos pocos y por eso se le acusa de haberse convertido en un lenguaje de élites (VERES, 2006: 15), en el sentido peyorativo que le da STEINER (2003: 16). No es un instrumento neutro ni aséptico de comunicación, sino que tiene ideología y permite dominar la realidad o escamotearla al conocimiento de los ciudadanos (LLEDÓ, 1970: 80 y CAYERO, 2014: 157). Entramos así en el universo conceptual de la política del lenguaje o glotopolítica que nos da herramientas para comprender las condiciones que articulan la lengua, la historia y la política (DEL VALLE, 2016: 17).

\subsection{El lenguaje jurídico como herramienta para la dirección de conductas}

Los lingüistas saben que el lenguaje no solo sirve para transmitir ideas, sino también para muchísimas cosas más: hacer bromas, agradecer, ordenar... Es lo que se denomina carácter multifuncional del lenguaje: tiene un uso emotivo, de liberación de impulsos irracionales y ejercicio de poder.

También en el ámbito jurídico, siguiendo los patrones de la lingüística cogniti$\mathrm{va}^{22}$, se recurre a palabras evocadoras de calculada ambigüedad terminológica, porque las palabras tienen efecto identitario y anestésico. DÍEZ SASTRE (2018: 141) habla de los iconos o las imágenes que evoca el lenguaje. Por ejemplo, no es neutro el uso de las palabras administrado, súbdito o ciudadano, usuario o cliente, contribuyente o sujeto pasivo en los textos jurídicos. O los términos emprendimiento, transparencia, empoderamiento, sostenibilidad. La selección de unos términos jurídicos en detrimento de otros permite orientar la conducta de los ciudadanos y el Derecho juega con esta ambigüedad calculada, disfrazado de lenguaje técnico y aséptico.

Los poderes públicos acuden a tácticas comunicativas como fundamento de la legitimidad del Derecho (OLIVER-LALANA, 2011: 261). Utilizan los moldes de la comunicación publicitaria, corporativa o de empresa (MOREU, 2005: 58) y los conocimientos de la psicología conductual (MOREU, 2018). Desde esta perspectiva, el lenguaje contribuye a la eficacia del Derecho, es decir, a que el destinatario cumpla

criterio de validez. La pretensión divulgativa del nuevo DEJ no impide que vaya a hacerse un hueco en la práctica legal y judicial, máxime cuando ya el Diccionario de la Real Academia de la Lengua Española funciona como criterio de interpretación relevante en los textos jurídicos. La importancia de estas herramientas se reconoce en la reciente declaración de Asunción-Paraguay adoptada en la XVIII Cumbre Judicial Iberoamericana (2016): "la elaboración y aprobación de un Diccionario Jurídico Panhispánico o Panamericano se constituirá en una obra de suma importancia en la unificación del léxico jurídico del orbe iberoamericano; y creemos que en dicho diccionario, sujeto en su redacción a las reglas de lexicografía, todos los países de habla hispana de Iberoamérica han de encontrar la expresión de la diversidad de su vocabulario jurídico".

22 La llamada lingüística cognitiva concibe el lenguaje como un sistema de patrones, estructuras o marcos (frames) que permite a los sujetos percibir y categorizar el mundo exterior a partir de experiencias propias (LAKOFF, 2004). 
u obedezca mejor las normas y demás manifestaciones del Derecho, y que estas sean aceptadas socialmente. En definitiva, el lenguaje utilizado es relevante para el objetivo de dirigir u orientar conductas. Un acto de comunicación jurídica puede tener consecuencias muy distintas sobre la conducta real de sus destinatarios en función de la fórmula lingüística o término empleado. Está comprobado, por ejemplo, que el recurso a presentaciones lúdicas e imágenes facilita el cumplimiento del Derecho. En Reino Unido se enviaron cartas a los contribuyentes que no habían pagado el impuesto de circulación de vehículos; cuando se incluyó una imagen del automóvil en cuestión, el pago se incrementó en un 10 por 100 .

\subsection{La magia de las palabras del Derecho}

Los juristas entendemos perfectamente que la llave para cambiar la realidad puede consistir simplemente en cambiar las palabras, como si tuvieran carácter mágico: invocando la palabra, la realidad cambia (VERES, 2006: 23). Si hacemos una ley de transparencia habrá transparencia, si hacemos una ley de fomento del emprendimiento, habrá emprendimiento y si reconocemos un derecho subjetivo a la vivienda habrá derecho subjetivo aunque no se articulen medios para hacerlo efectivo. El lenguaje jurídico es mágico: crea-modula la realidad, selecciona lo que tiene valor jurídico y determina en qué sentido tiene valor; por eso decíamos que es un arma de poder. El simple hecho de que una palabra esté o no en la norma tiene una enorme relevancia jurídica: las palabras luchan por aparecer en las normas ${ }^{23}$.

La realidad del derecho no es virtual porque los conceptos jurídicos se ajustan a problemas reales (GÓMEZ, 2005: 104). Sin embargo, en el lenguaje jurídico aparece muy difuminada la distinción entre enunciados descriptivos que se alcanzan con conocimiento empírico (como los conceptos: red de telecomunicaciones, terraza a nivel o vehículo de motor) y los prescriptivos (caducidad, interés público y otros). El lenguaje jurídico no sirve únicamente para nombrar hechos conocidos a través de los sentidos, de la memoria o de la inducción, sino que sirve también para expresar emociones, para provocarlas y para influir en la conducta, así que más bien modulacrea-conforma la realidad (BERMAN, 2013). DARNACULLETA (2016: 49) explica muy bien que el término "globalización" o "Derecho administrativo global" constituye "un intento de los profesores de Derecho público de convertir en realidad a través del lenguaje un proyecto de la globalización que integre los valores que han formado parte de su acervo conceptual".

Por otro lado, es muy complicado crear la terminología adecuada para las nuevas realidades jurídicas. ¿Cómo y por qué se atribuyen los nomen iuris a los nuevos conceptos? ¿Existe algún criterio para ello? ¿Y qué aporta este enfoque lingüístico a

${ }^{23}$ En el ámbito sanitario, por ejemplo, la simple mención es clave para el tratamiento asistencial de ciertas enfermedades. El síndrome de fatiga crónica, la sensibilidad química múltiple y otras enfermedades no existen para el Derecho mientras no estén incluidas en el registro nacional de enfermedades raras o se incluyan de alguna en el catálogo (ENTRENA RUIZ, 2017: 25). 
la dogmática jurídica? Prescindiendo de la etimología y del origen histórico del vocabulario jurídico, la selección de las palabras de los conceptos jurídicos obedece tanto a la arbitrariedad como a la necesidad, a la creatividad como a la reflexión, y suele ser intencional porque, desde luego, el lenguaje jurídico no es neutro.

El nuevo término puede nacer por impacto del derecho comunitario, que provoca su arraigo (poder adjudicador, obligación de servicio público, servicios sociales de interés general, servicios de interés económico general). Otras veces los términos parecen crearse sin reflexión, por moda o porque sí, especialmente cuando se trata de nuevos principios (sostenibilidad, transparencia, emprendimiento, LGTBIfobia, economía colaborativa), sin calibrar que en el momento en que una palabra se incorpora a la norma ya surgen importantes consecuencias jurídicas ${ }^{24}$. Existen, además, palabras que se introducen para sustituir a otras inconvenientes, poco apropiadas y "jurídicamente incorrectas" en el lenguaje jurídico, como discapacidad, en lugar de deficiencia ${ }^{25}$. MARTÍN REBOLLO (2018: 162) critica que las palabras envuelven conceptos cada vez menos asibles, más imprecisos y que las leyes se llenan de palabras vacías.

Los juristas nos movemos entre corrientes contradictorias de creatividad lingüística, cuando es necesario etiquetar los nuevos problemas jurídicos, e inflexibilidad y rigidez, y por eso ciertos cambios legislativos resultan confusos para el intérprete, porque alteran los cimientos de su construcción dogmática. Como denuncia con ironía SALVADOR (2004: 637), la tendencia a hacer literatura desde los textos legales es un despropósito y al legislador habría que exigirle, simplemente que llamen "pan al pan y al vino, vino". Además, tendemos a reconducir las nuevas realidades hacia el vocabulario jurídico ya conocido, en un proceso de retroalimentación que no siempre culmina con la creación de un nuevo término jurídico ${ }^{26}$. Incluso tengo la sensación de que nos enredamos en cuestiones lingüísticas irrelevantes; al

${ }^{24}$ Estas palabras de moda actuarían como tópicos del razonamiento jurídico, entendidos como lugares comunes que sirven para la retórica, para convencer al auditorio. Ciertas palabras son puro recurso retórico del jurista. Por ejemplo, en la mediática STS 459/2019 conocida como "la sentencia del procès" los acusados plantearon una eventual vulneración de su derecho procesal a utilizar la lengua catalana. En su argumentación, la Sala de lo Penal del Tribunal Supremo no se limita a aplicar la norma procesal que dispone que el catalán solo se usa en los órganos judiciales de Cataluña, sino que cita constantemente el tópico de la importancia de las lenguas y del plurilingüismo en España para blindar mejor su decisión (FJ. 3).

Por eso, como veremos, CAZORLA (2007: 77) sitúa el enfoque tópico y casuístico del Derecho como una de las causas de la degradación del lenguaje jurídico.

25 El preámbulo de la LO 8/2015, de reforma del sistema de protección a la infancia y la adolescencia justifica el cambio de denominación para "adaptar el lenguaje" a la Convención de Derechos de las personas con discapacidad de 13 de diciembre de 2006.

26 "Uno de los principales problemas que plantea la economía colaborativa es que, con frecuencia, muchas de las normas jurídicas vigentes en los ámbitos en los que aquella está comenzando a desplegarse han quedado obsoletas, por cuanto no tienen suficientemente en cuenta las posibilidades y peculiaridades que la misma presenta. Se trata de normas pensadas para una realidad distinta de la actual, en la que las referidas transacciones eran prácticamente imposibles" (DOMÉNECH, 2016). Un ejemplo más de ese "conservadurismo terminológico" que conduce a encajar las realidades jurídicas en etiquetas ya conocidas. 
fin y al cabo, el legislador es libre para dotar de significados nuevos a significantes jurídicos ${ }^{27}$.

\subsubsection{Términos comunes y "semitécnicos"}

Un porcentaje elevado de términos del lenguaje jurídico son los propios del lenguaje común ${ }^{28}$. Cuando un término del lenguaje común tiene un significado adicional y propio de la jerga jurídica se considera "semitécnico" (GÓMEZ BORRÁS, 2005: 99). Además, los juristas somos muy audaces en la creación de palabras nuevas a partir de los términos comunes (ALCARAZ, HUGUES, 2002:26), llegando a forzar las reglas lingüísticas; no es raro encontrar en los textos jurídicos palabras como usabilidad, alienidad, que no se recogen en el Diccionario de la Real Academia de la Lengua Española.

Cuanto más cercano esté el concepto jurídico a su significado en el lenguaje común, mejor se garantizará su comprensión; paradójicamente, el lenguaje común, por su ambigüedad semántica y sintáctica, es mucho más impreciso y está sujeto a mayores posibilidades interpretativas (BUENAGA, 2016: 140). A juicio de DÍEZ SASTRE (2018: 193), existe una diferencia esencial entre los términos del lenguaje común y los conceptos dogmáticos del Derecho, ya que los primeros "no admiten modulación por el Derecho y simplemente se asumen por él", mientras que los segundos son absolutamente moldeables por el Derecho. Solo comparto parcialmente esta afirmación, porque también los términos del lenguaje común podrían tener un significado propio para el Derecho y pueden ser acotados por él. Conceptos jurídicos como familia o matrimonio, incluso términos biológicos como hombre y mujer, no son descriptivos, sino eminentemente valorativos y creación del Derecho ${ }^{29}$.

\subsubsection{Tecnicismos}

En tanto que lengua de especialidad, el Derecho utiliza una terminología propia y exclusiva que no tiene significado fuera del mundo jurídico (dolo, enfiteusis, lucro cesante, interdicto, fuerza mayor). Prescindiendo aquí de los esfuerzos doctrinales para

27 Y así, cuando la ley llama "pena" a la sanción de la empresa, GRACIA MARTÍN (2016: 9) considera que estamos ante una contaminación semántica del lenguaje y un arbitrario tratamiento igual de lo que es desigual.

${ }^{28}$ En el caso del lenguaje administrativo, por ejemplo, CASTELLÓN (2006: 188) calcula que aproximadamente el 30 por 100 de los términos del Manual de Estilo del Lenguaje Administrativo (MELA) conoce un uso semejante al lenguaje común (por ejemplo: escrito, resolver, estimar, sancionar), mientras que el 60 por 100 posee un significado ajeno (como interés, auto, silencio, participación).

29 La Ley 3/2007, de 15 de marzo, reguladora de la rectificación registral de la mención relativa al sexo de las personas, permite la rectificación de la mención registral del sexo, sin necesidad de cirugía, cuando dicha inscripción no se corresponde con la verdadera identidad de género (art. 4.2). Otro término aparentemente neutro como todos del art. 15 de la Constitución encierra una cuestión ideológica entre quienes incluyen o excluyen al nasciturus. 
clasificar o encapsular los tecnicismos jurídicos, estamos ante términos normalmente unívocos y, desde luego, medulares para la formación de los conceptos jurídicos ${ }^{30}$.

Pero, si bien los tecnicismos reducen las dificultades interpretativas que presenta la aplicación de un concepto jurídico, agrandan los problemas de comprensión del lenguaje jurídico para el ciudadano medio ${ }^{31}$. En palabras de DÍEZ SASTRE (2018: 194) su uso implica "la mayor violación posible del criterio de la familiaridad". Lo cierto es que tampoco los tecnicismos escapan de la imprecisión, por su propia formulación abstracta y por el encorsetamiento del lenguaje ${ }^{32}$. Encontrar el equilibrio entre la precisión del tecnicismo y la necesidad de ser comprendido por los destinatarios es una tarea compleja, pero no imposible.

\subsubsection{Latinismos}

Aparte de que muchos tecnicismos jurídicos proceden del Derecho romano y tienen etimología latina, el lenguaje jurídico se caracteriza por la presencia de muchos latinismos puros (sine die, ratio decidenci, de lege ferenda). Parece una paradoja que subsistan en la época actual, en la que tan despiadadamente se arremete contra el latín y en general contra la cultura clásica y las viejas humanidades (HERRERO, 1995: 14). En todo caso, la influencia universal del latín facilita encontrar semejanzas entre términos jurídicos de distintas lenguas que actúan como tópicos para nuestra tarea hermenéutica.

Lo cierto es que las corrientes simplificadoras del lenguaje jurídico abogan por la reducción o la total eliminación de los latinismos. Se dice que su uso entorpece la comprensión del texto jurídico y que, además, los juristas los desnaturalizan y emplean mal (GÓMEZ FONT, 2009: 195). La declaración de Asunción-Paraguay adoptada en la XVIII Cumbre Judicial Iberoamericana (2016), parece inclinarse por la

${ }^{30} \mathrm{La}$ introducción de tecnicismos en el lenguaje jurídico se produce de distintas formas (CASTELLÓN, 2001: 75). La más habitual se da cuando los textos incorporan tecnicismos que pasan a integrar el lenguaje jurídico, incluso con definiciones y acotaciones metalingüísticas que concretan su significado. Otras veces, el texto técnico se incorpora como elemento estructural de la decisión jurídica, como los pliegos de prescripciones técnicas de un procedimiento de contratación, las declaraciones de impacto ambiental o los informes médicos que sirven de fundamento a la responsabilidad patrimonial.

${ }^{31}$ La complejidad técnica del lenguaje jurídico puede alcanzar repercusión mediática, como sucedió con la normativa de becas y ayudas al estudio regulada, entre otros, por RD 609/2013, de 2 de agosto. La norma introduce fórmulas matemáticas para calcular las denominadas "cuantías fijas" y "variables" de muy compleja comprensión, no sólo para los juristas-aplicadores del derecho. El recurso fue resuelto por STC 95/2016, 12 de mayo, y, precisamente, el voto particular del magistrado González Rivas insiste en la complejidad del sistema de cálculo de las becas para justificar una gestión centralizada en manos del Estado.

32 Por eso resulta clave la tarea hermenéutica del jurista. Por ejemplo, la SAN 2691/2015, ECLI: ES:AN:2015:2691, afirma en relación con el concepto de "riesgo y ventura" que "(...) ofrecen en el lenguaje jurídico y gramatical la configuración de la expresión riesgo como contingencia o proximidad de un daño y ventura como palabra que expresa que una cosa se expone a la contingencia de que suceda un mal o un bien" (FJ. 4). 
desaparición de las frases en latín de los textos jurídicos. La expulsión absoluta de los latinismos no se ha recogido formalmente en el "Prontuario de estilo" para el Tribunal Supremo, aprobado por su sala de gobierno por acuerdo de 19 de enero de 2016.

\subsubsection{Neologismos, extranjerismos, préstamos lingüisticos}

El lenguaje jurídico emplea numerosos tecnicismos no jurídicos importados de otros ámbitos del saber (las matemáticas, la economía, la medicina, la ingeniería, la arquitectura, la estadística, la informática), que se introducen en los textos jurídicos. Como el método jurídico tiende progresivamente a la interdisciplinariedad y presta una mayor atención a los hechos y a los datos (CHYNOWETH, 2008: 31), no debería extrañarnos esta invasión de neologismos. La remisión a normas técnicas y, muy especialmente, la globalización y el Derecho comunitario, son factores que explicarían dicho fenómeno.

Los neologismos esconden la necesidad de atribuir una palabra que defina las nuevas necesidades sociales, fruto de la evolución de la vida económica, social, mentalidad e instituciones. En la clasificación de DÍEZ SASTRE (2015 y 2018), se identificarían con esos conceptos clave y puente que trazan rutas de análisis en la ciencia jurídica y abren caminos para nuevas investigaciones o para repensar el Derecho existente (como desregulación, sostenibilidad, transparencia, globalización).

También la importación de términos de otros idiomas es cada vez más habitual por el impacto de la unificación europea, el recurso a la herramienta del Derecho comparado y las nuevas tecnologías. El empleo de extranjerismos (software, trust, handling, accountability, copypright, y otros) en los textos jurídicos, sobre todo en los académicos pero también en los normativos, constituye una lacra del lenguaje jurídico actual, a juicio de CAZORLA (2007: 103 y 2008: 345). El Libro de Estilo de la Justicia (2017) considera que son un factor desestabilizador de nuestro sistema ortográfico. Y no solo es una cuestión terminológica o de estilo, sino también semántica: la importación de términos de sistemas jurídicos extranjeros plantea, entre otros, el problema de su fijación y su resonancia, es decir, la viabilidad de que el concepto se consolide (DÍEZ SASTRE, 2018: 187).

\subsection{La interpretación de las palabras del Derecho}

A pesar de que el lenguaje jurídico se construye formalmente sobre el lenguaje común, un buen dominio de la lengua propia no garantiza la comunicación entre sujetos. El lenguaje jurídico "paralizado en letra" (LLEDÓ, 1970: 119) necesita de la hermenéutica. Para que el texto jurídico se pueda aplicar a hechos y situaciones concretas que afectan a los ciudadanos es necesario clarificar —interpretar, traducir- su significado. La hermenéutica encierra las tres tareas básicas del jurista: identificar las normas jurídicas (que son textos lingüísticos y actos de habla), exponer sus conte- 
nidos, interpretando los textos, y crear un sistema ordenado con ellas, formulando conceptos y principios.

Interpretar consiste en transformar los signos lingüísticos del texto jurídico (la sentencia, el dictamen, el acto administrativo) en otro conjunto de signos expresados a través del lenguaje. Lo escrito en la norma solo cobra vida cuando alguien lo lee (FROSINI, 1995: 22). Esta mutación no es matemática, porque los enunciados jurídicos tienen, como cualquier enunciado del lenguaje común, una dimensión pragmática. Los juristas debemos asumir que el derecho es un proceso comunicativo y dirigir su atención hacia los textos jurídicos como procesos de comunicación en su contexto (LÓPEZ HERNÁNDEZ, 2012: 101). Lo cierto es que los cánones tradicionales de la hermenéutica jurídica ya incluyen algunas reglas sobre la textualidad del lenguaje. ¿ $\mathrm{O}$ no es eso, precisamente, lo que dispone el art. 3.1 del Código Civil cuando se refiere al contexto, la realidad social, el espíritu y la finalidad de las normas?

\subsubsection{La tarea hermenéutica del jurista}

El Derecho es una forma de expresión lingüística y su interpretación es tarea esencial del jurista. La hermenéutica jurídica tiene por objeto los conceptos jurídicos y crea los suyos propios y por eso algunos consideran que es un metalenguaje (GÓMEZ BORRÁS, 2005: 115). En unos casos, con el monopolio en su aplicación-interpretación (como los jueces y magistrados) y, en otros casos con una función menos definida y sin cauces de exigencia o intercomunicación, como los profesores universitarios, juristas académicos (la doctrina), que se expresan en sus monografías, artículos y revistas especializadas (TOHARIA, 2006: 9). Precisamente, uno de los agujeros de la hermenéutica jurídica es que la comunicación doctrinal no alcanza difusión fuera del ámbito académico, y que tampoco hay cauces adecuados de creación jurisprudencial.

¿Qué elementos caracterizan el lenguaje de los juristas en su tarea hermenéutica? En el lenguaje de la interpretación también existen diferencias, porque diferentes son las funciones de sus emisores desde un punto de vista pragmático. No todos los intérpretes del lenguaje jurídico tienen el mismo interés ni hablan en idéntico contexto. El juez, por ejemplo, debe ser fiel a la letra de la ley, mientras que el abogado lo es al interés de sus clientes (FROSINI, 1995: 26). En cambio, los juristas académicos son los principales creadores de la neología jurídica, y por esa razón se les permite mayor grado de abstracción e incomprensión, dado que los cauces de interconexión con el exterior son más limitados.

Podríamos afirmar que la característica fundamental del lenguaje hermenéutico es que sus destinatarios principales no son los ciudadanos, sino los demás juristas, hablantes todos de la misma jerga juridica. De este modo, las exigencias de claridad se reducen, hay mayor libertad porque no están en juego los derechos de los ciudadanos, al menos no directamente. El lenguaje viene marcado por el estilo personal de cada jurista (CAZORLA, 2007: 138). En cualquier caso, todos persiguen ganarse la credibilidad de sus colegas de profesión, con miras a su progresión profesional o académica. En el 
caso de los juristas académicos, a la sazón docentes universitarios, la libertad con la que utilizan la jerga jurídica puede acabar alejándolos de los demás destinatarios de sus mensajes: sus estudiantes.

Por otro lado, la extensión de las tecnologías y el uso de las redes sociales entre la comunidad jurídica está provocando cambios en el lenguaje hermenéutico. Las nuevas vías de difusión alcanzan a mayor número de destinatarios y el lenguaje se hace menos técnico y formal. Son textos con un tono divulgativo, más informales que los difundidos a través de publicaciones tradicionales y revistas científicas, porque la intención del emisor es distinta. Y eso que en España se observa un escaso o nulo interés entre los juristas por escribir libros jurídicos divulgativos para el gran público, que quizás cambie si se consolida el conocido como "sexenio de transferencia".

La permeabilidad entre las contribuciones doctrinales de cada época determina también la evolución del lenguaje jurídico. Actualmente, la doctrina jurídica está más influida por el Derecho estadounidense y esto condiciona tanto el uso del inglés como lengua vehicular del lenguaje interpretativo, como el acercamiento de los ordenamientos nacionales en un entorno global, como veremos en un epígrafe posterior.

En todo caso, la tarea hermenéutica del jurista queda condicionada por ciertas peculiaridades del lenguaje jurídico que ya han quedado apuntadas:

(a) En primer lugar, el lenguaje del derecho no es colaborativo porque, salvo excepciones, no existe una relación directa entre el emisor y el receptor (ITURRALDE, 2014: 78). Es una relación unidireccional en la que no hay posibilidad de diálogo para aclarar el sentido de las expresiones, a diferencia de lo que ocurre en la comunicación directa y esta característica es uno de los escollos para la comprensión del texto. El emisor-legislador no es una persona física e incluye órganos muy diversos, incluso administraciones públicas, así que no es fácil averiguar cuál es la "voluntad del legislador". Incluso da la impresión de que el propio autor de la norma no está interesado en que se produzca una comunicación colaborativa, a juzgar por los defectos de técnica normativa (ambigüedades semánticas, sintácticas) y complejidades innecesarias que se podrían haber evitado.

(b) Por otro lado, el Derecho es un fenómeno institucional, que establece una relación de poder/sumisión entre el emisor y los destinatarios. Esta característica potencia la inestabilidad de la terminología jurídica que se modula y se adapta fácilmente al contexto (ITURRALDE, 2014: 85) ${ }^{33}$.

33 Un ejemplo de este uso político del lenguaje jurídico en la STS 8574/1992 (ECLI:ES:TS: 1992:8574) cuando reconoce que "el fondo del asunto no es académico o lingüístico (...) sino político", en relación con el uso de la palabra "catalán" para designar la lengua que se habla en la comunidad autónoma valenciana. 


\subsubsection{El canon literal}

De todos es sabido que el canon literal, gramatical o lingüístico es uno de los criterios hermenéuticos del art. 3.1 del Código Civil: una interpretación es objetivamente admisible cuando es compatible con las reglas semánticas, sintácticas y pragmáticas del lenguaje. En la tarea hermenéutica del jurista, los términos del lenguaje ordinario se pueden aplicar con otro significado distinto y lo mismo cabe decir de las palabras prestadas de otras disciplinas, que quedan filtradas por el razonamiento jurídico. Sin embargo, constata KLATT (2017: 40), que la interpretación semántica o literal del derecho ha sufrido un menosprecio histórico

El derecho padece las limitaciones propias del lenguaje común que utiliza como herramienta de transmisión, entre ellas, la vaguedad o la contextualidad de su significado (ALEXY, 1983: 23). Quizás por esa razón, la metodología jurídica no ha sido capaz de establecer criterios infalibles ni siquiera para delimitar la interpretación lingüística de los conceptos jurídicos (ITURRALDE, 2014: 107). Podríamos llegar a reducir la vaguedad de un término jurídico a través de sucesivas definiciones, como es habitual en los textos normativos, pero llegará un momento en que el lenguaje no permite precisar más. La imprecisión es algo inevitable y consustancial al lenguaje del Derecho y por eso no se considera contrario al principio de seguridad jurídica. Así lo ha expresado el Tribunal Supremo:

“(...) la práctica totalidad del art. 1 del Decreto se dedica a precisar su ámbito de aplicación, con inclusión de definiciones y requisitos; que el resultado conseguido pueda presentar problemas interpretativos derivados del grado de indeterminación inherente al lenguaje (de las alternativas de los significados lingüísticos) no comporta, por lo general, la vulneración de la seguridad jurídica, sino que las precisiones vendrán de mano de la doctrina o de la interpretación llevada a cabo por los órganos judiciales, constituyendo ésta de la interpretación una tarea habitual de los juristas", STS 3669/2013, FJ. 2.

En relación con el argumento literal me parece bastante equilibrada la tesis que propone GARCÍA AMADO (2013) que serviría, precisamente, para delimitar cuáles son las interpretaciones posibles de un término o expresión jurídica, acotando el campo de juego para los demás criterios hermenéuticos, si fuesen necesarios. Es decir: la regla lingüística marcaría la frontera entre los casos fáciles y los difíciles a efectos hermenéuticos. Los casos fáciles podrían resolverse con un mero argumento literal o lingüístico, mientras que los difíciles permiten opciones interpretativas aplicando un razonamiento analógico, teleológico, histórico, finalista o cualquier otro (los criterios del Código Civil no son rígidos).

Sin embargo, lo cierto es que un concepto jurídico no se puede definir exclusivamente como un simple conjunto de expresiones lingüísticas ${ }^{34}$. El sentido literal de las palabras puede entrar en abierta contradicción con el contexto y con las opiniones

${ }^{34}$ Así como los lingüistas distinguen entre significante (enunciado o expresión lingüística) y significado (proposición) de un texto, la dogmática jurídica parte también de una distinción entre la expresión o enunciado de la norma y su significado. Los teóricos del Derecho han asumido al respecto dos posiciones ontológicas contrapuestas: la concepción expresiva identifica la norma con la expresión lingüística, 
que tienen los intérpretes y aplicadores del Derecho. Y no solo eso: el excesivo formalismo jurídico se considera un freno para alcanzar la justicia (ATIENZA, 2013: 29).

Con estas premisas, el carácter convencional del lenguaje jurídico y subjetivo de la argumentación jurídica (HABA, 2003) conduce a replantear la función de la metodología jurídica y de sus herramientas hermenéuticas, como insinúa NIETO (2000: 158) cuando denuncia la "inutilidad radical" de la argumentación jurídica, "porque nadie escucha razones: el vencedor porque no las necesita y el perdedor porque nunca podrá ser convencido". Si el lenguaje jurídico es confuso e indeterminado porque no existe un solo sentido correcto de los términos jurídicos, su aplicación e interpretación es también contingente, ilógica, sujeta a los "juegos del lenguaje” y a las reglas de la persuasión.

\subsection{Modelando los conceptos jurídicos a través del lenguaje: el método conceptual aplicado al Derecho}

Profundizando en el análisis semántico, que se ocupa del significado de los signos lingüísticos, e insistiendo en ese giro lingüístico que queremos dar a la metodología de la investigación jurídica, concluiremos que las palabras del lenguaje jurídico "conservan la historia de su evolución" (ROSELLI, 2013: 5). Ocurre que, con el paso del tiempo, un término jurídico puede quedar vacío de contenido o referirse a una realidad jurídica muy diferente de la que tenía cuando se forjó. Las palabras van perdiendo sus viejos sentidos y adquieren otros nuevos, o en algunos casos no adquieren ninguno y son "palabras vacías" o "huecas", en un sentido similar al de OLIVECRONA (1962: 59). Resulta fácil advertir que, con el devenir histórico muchos términos jurídicos han perdido su sentido originario (como servicio público o policía); otros superponen viejos y nuevos significados (como administración pública, sector público o dominio público) y otros se actualizan (como gobernanza, emprendimiento, transparencia). El uso del lenguaje jurídico es indicativo de la historia social subyacente $^{35}$. Según el Diccionario de la Real Academia de la Lengua Española, una logomaquia es un conflicto léxico que atiende a las palabras y no al fondo del asunto. Sin embargo, puede esconder un cambio social y político profundo, no meramente formal o nominalista, especialmente en el ámbito del lenguaje jurídico.

mientras que la concepción semántica se centra en el significado de la norma, es decir, en el sentido o contenido valorativo del texto más allá de las palabras.

35 En su conocido ensayo La lengua de los Derechos [que constituyó su discurso de ingreso en la Real Academia Española en 1994] y en otro menos conocido titulado " 418 palabras que cambiaron el mundo”, García de Enterría se recrea en ese nuevo lenguaje jurídico que nace de la Revolución francesa. La imagen se resume en esta reveladora cita de Montesquieu: "Yo he tenido ideas nuevas: ha habido necesidad por tanto de encontrar nuevas palabras o de dar a las antiguas nuevas significaciones" [De l'Esprit des Lois, 1757]. Por primera vez en la historia de las revoluciones humanas no se trataba de sustituir el poder establecido, sino de rectificar la historia entera, fundar un orden político y social totalmente nuevo, una nueva etapa, incluso la idea de un "hombre nuevo". "No es extraño, por eso, que la Revolución francesa tuviese efectos inmediatos sobre la lengua" (GARCÍA DE ENTERRÍA, 1994: 26). 
La historia conceptual nos ofrece una herramienta para elaborar metodológicamente estas sacudidas del lenguaje.

La historia de los conceptos (Begriffsgeschichte) se abre paso en el escenario internacional como una corriente metodológica estimulante que promueve investigaciones comparativas e interdisciplinares en las ciencias sociales, siendo uno de sus más conocidos impulsores el historiador alemán R. Koselleck. Esta línea metodológica parte de la idea de la inestabilidad del lenguaje, que es una realidad viva que se transforma (DUARTE, 1990: 96). La historia conceptual advierte que determinados conceptos (de la historia, la política...) han sufrido grandes variaciones semánticas a lo largo del tiempo sin que tales cambios hayan supuesto el nacimiento de nuevas palabras, pues el vocabulario (político, histórico) básico se ha mantenido estable. En definitiva: las palabras que se han conservado a lo largo del tiempo no son indicio suficiente de que las circunstancias hayan permanecido igual. KOSELLECK (2000: 35) lo expresa magníficamente al escribir que su objetivo es "asir el tiempo lingüísticamente"36.

Se trataría de descubrir el sistema de capas que subyace en el léxico de los conceptos jurídicos, en expresión de CAPPELLINI (2010: 170). Bajo la apariencia de asepsia técnica de algunos términos del lenguaje jurídico se esconde un sustrato ideológico que hay que desvelar. La historia conceptual contempla el lenguaje como una herramienta para la ocultación del pensamiento (CASTELLÓN, 2006: 185). Nos aferramos a las palabras para transformar la realidad. En el lenguaje jurídico encontramos ejemplos de ocultación a través del lenguaje (así ocurre con los conceptos mágicos de transparencia, sostenibilidad, racionalización, emprendimiento). Efectivamente, VAQUER (2014: 3020) constata que el significante y el significado de los

36 La historia conceptual muestra las etapas en la formación de las palabras y de los conceptos. Permanencia y cambio se captan diacrónicamente a lo largo de los significados y del uso del lenguaje. Cuando irrumpe algo completamente nuevo se suele recurrir al "lenguaje dado" o el "patrimonio lingüístico", y por eso, con el devenir histórico el lenguaje se actualiza una y otra vez y se va modificando lentamente. El tempo de los conceptos no es el tempo de las estructuras sociales y políticas. En sus contribuciones fundamentales para la historia del pensamiento español, con interesantísimos estudios en torno a los términos de nación, historia, industria, felicidad o civilización, MARAVALL (1991: 429) destaca la importancia que tienen los cambios léxicos y semánticos como indicadores básicos de transformaciones sociales $y$ de nueva ubicación de ciertas relaciones y visión del mundo circundante. Este vocabulario es expresión de las experiencias fundamentales por las que ha pasado un grupo humano en una época determinada.

Para la historia conceptual, las palabras son indicadores de determinados contextos sociales y políticos, pero constituyen, asimismo, factores internos de la propia realidad y de su transformación. KOSELLECK (1979: 123) distingue entre historia de "palabras" (o "ideas"), e historia de "conceptos". Entre palabras y conceptos hay un vínculo externo. Las palabras son eternas por definición. El análisis histórico de las mismas solo verifica su presencia o no en un contexto particular, pero no nos dice nada acerca de su significado y de las alteraciones que en él se producen. Solo cuando un término o idea se carga de connotaciones particulares diversas se convierte en lo que Koselleck llama un "concepto". En un concepto se encuentran siempre sedimentados sentidos correspondientes a épocas y circunstancias de enunciación diversas, que se ponen en juego en cada uno de sus usos efectivos. Koselleck emplea la metáfora de los "estratos del tiempo", que remite a formaciones geológicas que alcanzan distintas dimensiones y profundidades, y que se han modificado y diferenciado a lo largo del tiempo a distintas velocidades. 
conceptos jurídicos son independientes, pero el significante tiene un valor sugestivo que condiciona la recepción del concepto, mientras que la rigidez de los conceptos casa mal con una realidad más inestable que nunca. Eso podría explicar los desfases entre los significantes y los significados del lenguaje jurídico. El proceso se acelera debido a la extensión de las nuevas tecnologías, la masa de datos e informaciones que crece sin límites, que se fragmenta y se descompone.

En conclusión, creo que la historia conceptual puede ser útil para el jurista, porque le ofrece herramientas para abordar ese proceso de validación y refutación de los conceptos jurídicos, que da lugar a su abandono o continuidad, y para estudiar la superposición y sedimentación de los conceptos del lenguaje jurídico en sus distintas etapas históricas ${ }^{37}$. Estamos ante un método integrador, interdisciplinar, que refleja muy bien las transformaciones actuales del Derecho y de la sociedad a la que sirve.

\section{PRAGMÁTICA DEL DERECHO}

Los juristas tendemos a ver el lenguaje como una especie de "materia transparente" que utilizamos para designar los conceptos, preceptos e instituciones, sin detenernos demasiado a reflexionar sobre los problemas derivados de su misma utilización (HERNANDO CUADRADO, 2003: 9). Por eso es conveniente tener a mano las herramientas del análisis pragmático, que incorpora diferentes variables para la comprensión del lenguaje jurídico, entre ellas: el contexto socio-cultural, los sujetos (emisor, destinatario) y el tono del mensaje ${ }^{38}$. La pragmática es una rama de la lingüística que se interesa por el modo en que el contexto (la situación comunicativa, el conocimiento compartido por los hablantes, las relaciones interpersonales, etc.) influye en la interpretación del significado de las palabras. Se trata, en definitiva, de tomar en consideración la influencia del contexto en el lenguaje jurídico y la relación que existe entre el Derecho y sus intérpretes (ESCANDELL, 2011: 26).

37 Por ejemplo, MIR (2003: 47) aborda esa perspectiva lingüística para explicar las transformaciones y la situación actual del concepto de derecho administrativo. También EMBID (2014: 6) ha analizado el lenguaje utilizado en el marco de la crisis económica, para resaltar las consecuencias jurídicas de "todo un aparataje normativo quiere sustentarse sobre un lenguaje que, en mi opinión, no tiene los suficientes elementos de claridad y en algunas ocasiones, además, parece utilizado desde un punto de vista más político que jurídico lo que solo puede llevar consigo confusión e incertidumbre, justo lo contrario de lo que hay que pedir a la norma, a cualquier norma". O los trabajos de DELGADO (2013) sobre el campo semántico "validez" en el Derecho español y de FERNÁNDEZ RODRÍGUEZ (2016) sobre el adjetivo "arbitrario".

38 Además, CALVO (1996: 77), VAN ROERMUND (1997), TARANILLA y YÚFERA (2012: 161) defienden que la aproximación al lenguaje jurídico puede hacerse desde la narrativa, ya que hay una función narrativa innegable en la labor del intérprete (juez, abogado) y en los textos que encauzan dicha labor hermenéutica (sentencia, demanda, etc.). El jurista, en su labor hermenéutica, se convierte en un contador de historias porque reformula con otras palabras los textos de las fuentes normativas, aunque no es capaz de narrar de un modo eficaz porque carece de las técnicas narrativas necesarias, y quizás también por sesgos como el "dilema de la doble audiencia" de Gibbons que ya se ha explicado. 


\subsection{Los sujetos de la comunicación jurídica}

Como he dicho, la aproximación al lenguaje jurídico exige establecer distintos niveles de textos y no tratarlos todos de la misma manera, pues la fuerza ilocutiva del texto jurídico depende de la intención y del uso que cada emisor hace del lenguaje. Desde un enfoque pragmático, está claro que existe un público del lenguaje jurídico (TOHARIA, 2006: 4), cuya evolución y características condiciona la del propio Derecho.

\subsubsection{El destinatario del Derecho}

El receptor o destinatario del derecho puede ser distinto según el género jurídico que tratemos. Cuanto más especializado sea el destinatario de la comunicación, más complejo puede ser el texto jurídico (PRIETO DE PEDRO, 1991: 172):

- En el caso de los textos normativos, su destinatario es el ciudadano, aunque las normas vayan a ser interpretadas y aplicadas por los profesionales del Derecho ${ }^{39}$. Las directrices de técnica normativa aprobadas por el Estado en 2005 enfatizan que "el destinatario de las normas jurídicas es el ciudadano", por lo que "deben redactarse en un nivel de lenguaje culto, pero accesible" (art. 101).

- También el destinatario del lenguaje administrativo es el ciudadano, si bien puede ir dirigido a públicos más especializados o técnicos (contratistas), además de a las propias instituciones y administraciones públicas. Por ejemplo, la tipología de usuarios de los servicios públicos condiciona el lenguaje jurídico empleado.

- También hay textos jurídicos de destinatario mixto, como los procesales, que van dirigidos tanto al jurista experto (abogado, procurador) como a los ciudadanos que son parte interesada en el proceso.

- Los textos jurídicos interpretativos (un dictamen, una publicación académica) tienen como destinatario exclusivo a los propios juristas.

Además hay que tener en cuenta que el lenguaje jurídico está muy atomizado porque se amolda a los distintos sectores o áreas de especialidad del ordenamiento jurídico (Derecho penal, civil, administrativo, etc.), y eso comporta diferencias lingüísticas que dificultan la comunicación incluso entre los propios juristas.

Atender al destinatario de la comunicación jurídica comporta cambios relevantes en la estructura formal del Derecho, pues estaremos de acuerdo en que no se puede entablar una comunicación jurídica si su principal destinatario no está en condiciones de comprender el mensaje. Solo los ciudadanos que tienen acceso a la

39 Es cierto que el destinatario de las normas no solo es el ciudadano, sino también el operador jurídico o el experto jurídico que las aplica. Además, el ciudadano no accede directamente a los textos, sino indirectamente a través del operador jurídico que "traduce" el Derecho a un lenguaje comprensible para él. Pero eso no impide considerar que es su principal destinatario. 
información y un buen dominio del lenguaje pueden participar activamente en la vida política, social y cultural. La simplificación del lenguaje jurídico se convierte así en objetivo y fundamento del Estado democrático (PRIETO DE PEDRO, 2016: $137)^{40}$, y obliga a los poderes públicos a adoptar medidas que faciliten el acceso y la comprensión de los textos jurídicos para sus destinatarios, y en algún caso con consecuencias jurídicas como la exoneración de su responsabilidad en caso de incumplimiento de la norma ${ }^{41}$. Para facilitar la comunicación jurídica es inevitable contar con agentes o elementos de conmutación lingüística, tales como oficinas de información, memorias redactadas con un lenguaje sencillo, instituciones intermedias, etc. (MARTÍNEZ BARGUEÑO, 1991: 222 y VILCHES, SARMIENTO, 2016: 17-30). Y, por supuesto, es preciso perfeccionar los canales de difusión de los mensajes, pues la simple publicación oficial no garantiza la transmisión del mensaje (FROSINI, 1995: 42).

\subsubsection{El emisor del Derecho}

Si el Derecho está formado por actos de habla y se crea "a golpe de decisión" tiene sentido hablar de los sujetos que hablan derecho, que toman decisiones en el mundo jurídico: los emisores de la comunicación jurídica (ROBLES, 2009: 60) ${ }^{42}$. En el lenguaje jurídico es fundamental el papel del emisor, más que en otros lenguajes de espe-

40 Un buen ejemplo de adaptación del lenguaje jurídico al perfil de sus destinatarios lo tenemos en el ámbito financiero. Desde la transposición de la Directiva sobre los Mercados de Instrumentos Financieros (MiFID) las normas que rigen las relaciones entre las entidades financieras y sus clientes garantizan que el destinatario de un determinado producto financiero esté convenientemente catalogado o clasificado en función de su experiencia y conocimiento de los mercados. A menor nivel de comprensión (ciudadano medio, cliente minorista), mayor protección ofrece la norma. Por ejemplo, la Ley del Mercado de Valores condiciona el contenido y el lenguaje de los folletos informativos que ofrecen las entidades financieras, cuyo incumplimiento podría suponer un vicio en el consentimiento (al respecto, STS 91/2016, ECLI:ES:TS:2016:91).

El lenguaje jurídico es especialmente sensible a sus destinatarios cuando estos son menores de edad, discapacitados o colectivos especialmente frágiles. En tales casos, la norma reconoce expresamente la conveniencia de utilizar un "lenguaje comprensible" (leyes de responsabilidad penal del menor, de servicios sociales y otras). El lenguaje jurídico dirigido a menores y otros colectivos vulnerables se sirve a menudo de imágenes y símbolos (así, las hojas de información al paciente menor de edad en el ámbito sanitario).

${ }^{41}$ Así ocurre en el ámbito tributario. La Ley General Tributaria obliga a que se publiquen los textos consolidados de la normativa tributaria y las resoluciones interpretativas más relevantes, para facilitar el acceso y comprensión de los ciudadanos (art. 86 LGT). Pues bien: si el obligado tributario respeta dichas publicaciones y comunicaciones, se presumirá que ha puesto la diligencia necesaria en el cumplimiento de sus obligaciones tributarias con eventual exoneración de su responsabilidad (art. 179.2 d) LGT).

42 La teoría del lenguaje como "actos de habla" se debe a los filósofos del lenguaje J.L. AUSTIN (1962) y J. SEARLE (1969), luego continuada por HABERMAS (1981). Según esta tesis, los enunciados del lenguaje tienen una intención comunicativa determinada (afirmar, prometer, ordenar) y un efecto, que es la reacción que provoca en el receptor (convencer, calmar, etc.). Por tanto, el contexto es fundamental para estudiar el lenguaje. 
cialidad. No todos estos sujetos emplean el lenguaje jurídico del mismo modo, como vimos, pues dependen del género jurídico. Unos pocos deciden o crean Derecho (el legislador, el gobierno), otros lo hacen cumplir (el juez, la administración) y otros lo describen, lo interpretan, lo sistematizan incluso en un nivel de metalenguaje (los abogados, los juristas académicos). El Derecho es un conjunto de actos y procesos de comunicación a través de canales altamente formalizados, porque no todos los actos de comunicación tienen relevancia jurídica, sino solo aquellos que el propio ordenamiento jurídico señala y que permiten deslindar el Derecho de otras disciplinas o ciencias (ROBLES, 2017: 13).

\subsection{Un diagnóstico demoledor: el lenguaje jurídico fracasa comunicativamente}

Está claro que un buen Derecho no es posible sin un buen lenguaje, y de ahí las críticas hacia la mala calidad de los textos jurídicos y los esfuerzos - a nivel nacional, internacional y especialmente en la Unión Europea, tan preocupada por su imagenpor mejorar y simplificar el lenguaje jurídico. Hace años que se alerta sobre la mala calidad, el empobrecimiento, la degradación y deterioro formal del lenguaje jurídico, el uso inadecuado de términos jurídicos, y el idiotismo expresivo del Derecho ${ }^{43}$.

¿Por qué el lenguaje jurídico es tan malo? ¿Qué factores contribuyen a esta situación? La baja calidad del lenguaje jurídico se achaca al impacto de los medios de comunicación de masas, a la falta de una política clara de defensa y promoción del español, a la dependencia del lenguaje político, a la invasión del inglés y a la debilidad de los estudios de lengua española en la escuela; el foco del problema se sitúa en la ineptitud para hablar en público en la era de las comunicaciones, en la judicialización de la política y en una deficitaria enseñanza secundaria.

Más ampliamente, la crisis del lenguaje jurídico se identifica con la crisis general del Derecho (PAMPARACUATRO, 2015: 171), vinculada con la desnaturalización de la ley y el desbordamiento del ordenamiento jurídico, la complejidad del entramado normativo, su fragmentación y su casuismo, así como la judicialización de la vida pública, la globalización, la baja calidad de la enseñanza, el impacto de las nuevas tecnologías y el predominio de lo visual (MUÑOZ MACHADO, 2005: 21). Se mencionan otras causas como nuestra formación en la tradición romanística, la

En España la teoría comunicacional del Derecho ha sido especialmente desarrollada por ROBLES, quien, frente al positivismo y la faceta coactiva del Derecho, propone su análisis como fenómeno de comunicación o, para ser más exactos, como un conjunto heterogéneo y complejo de procesos de comunicación que se concretan en textos, los textos jurídicos. Una revisión reciente de sus tesis en la obra colectiva de D. MEDINA, coord. (2017), que destacan que la teoría elaborada por el profesor ROBLES es una "importante herramienta de análisis del fenómeno jurídico".

43 Por todos, CALVO (1980: 257), PRIETO DE PEDRO (1991: 103), MARTÍNEZ BARGUEÑO (1991: 230), OLIVENCIA (1999: 14), CASTELLÓN (2001: 260), GONZÁLEZ CASADO (2005: 235), CAZORLA (2007: 39-49), CONDE (2009), GUASTINI (2016) y CARRETERO, FUENTES (2019: 7). 
solemnidad y la teatralidad propias del Derecho, la necesidad de precisión y también la comodidad del jurista (BIEGER, 2006: 38). Para CAZORLA (2007 :77) el enfoque tópico y casuístico del Derecho, contrario a la formulación de categorías generales, las debilita y es responsable de la degradación del lenguaje jurídico. VAQUER (2014: 3019) advierte que la fragmentación y la diversidad conceptual están detrás del fin de las grandes teorías en el ámbito del Derecho público, porque complica la construcción de conceptos unitarios y teorías generales. Paradójicamente, son "más necesarios que nunca, pero más difíciles que nunca”.

En fin, es propio del ser humano añorar con melancolía "cualquier tiempo pasado" (como si siempre hubiera sido mejor). Sin embargo, hay estudios que demuestran que la lengua no es hoy más pobre que en épocas pasadas: es diferente, como la sociedad, ni mejor ni peor, solo diferente (SÁNCHEZ LOBATO, 2006: 29). El mundo del Derecho ha experimentado las mismas variaciones que la sociedad que lo sustenta y eso altera profundamente la labor del jurista y, por tanto, su lenguaje (TOHARIA, 2006:1). Ya hemos visto cómo la imagen, las nuevas tecnologías o la inteligencia artificial modifican sustancialmente el lenguaje del Derecho, y con él el método jurídico. Estamos, simplemente, ante un proceso natural de transformación lingüística.

\subsection{El derecho a comprender el lenguaje jurídico}

Como se ha dicho, los textos jurídicos resultan incomprensibles para la mayoría de los ciudadanos, que son sus principales destinatarios ${ }^{44}$. Paradójicamente, la eficacia del Derecho es una exigencia constitucional que deriva del sometimiento de los ciudadanos a las normas y al resto del ordenamiento jurídico (art. 9.1 de la Constitución); recordemos que la ignorancia de las leyes no exime de su cumplimiento (art. 6.1 del Código Civil). OLIVER-LALANA (2011:2) pone de relieve esta paradoja: el Derecho es una realidad oscura para la gran mayoría de las personas, pero su capacidad de comprensión es condición necesaria para su legitimidad ${ }^{45}$. Uno de los

44 Así lo reconoce el trabajo de campo sobre "El lenguaje de las normas" elaborado por la CMLJ $(2011,5)$ : cuanto más afectado está el ciudadano por el lenguaje jurídico, menos parece comprenderlo.

En esta parte del trabajo dedicada a la comprensión del lenguaje jurídico no podemos dejar de mencionar, siquiera tangencialmente, el estatuto jurídico de las lenguas cooficiales y las políticas de normalización lingüística, una de las conexiones entre lenguaje y Derecho que más han ocupado la atención de los juristas (PRIETO DE PEDRO, 1991: 27). La reivindicación del lenguaje jurídico propio guarda relación evidente con el hecho diferencial de la lengua en un determinado contexto político ["la modernización del lenguaje jurídico catalán es fruto de un alejamiento de un castellano jurídico asociado con formas de hacer desfasadas", DUARTE 2012: 128)]. En definitiva, la distribución territorial del poder y la coexistencia de lenguas cooficiales genera problemas terminológicos y de traducción propios de nuestro país (FONT, 2006, 108). Además, España es un país con más de cuatro millones de ciudadanos extranjeros y el objetivo de comprensión del lenguaje jurídico debe hacer frente también a contextos multilingües.

${ }^{45}$ No faltan voces, críticas e irónicas, que afirman que "el Derecho funciona gracias a que la gente no sabe lo que es; si de verdad lo supiera, no podría funcionar porque no habría esa máquina de confianza que es la que mueve en el fondo el Derecho" (OLLERO, 1999: 106). 
mayores retos de la teoría comunicativa de la legitimidad del Derecho es conciliar ambos enunciados.

Por eso el lenguaje debe ser eficaz, en el sentido de ser comprensible por sus destinatarios y, poco a poco, este objetivo está calando en legisladores, gobiernos y administraciones públicas ${ }^{46}$. Se advierte un cambio de percepción que conduce a una nueva cultura comunicativa, a querer mejorar la imagen externa de las instituciones, a conseguir una administración más cercana y transparente (MARTÍNEZ BARGUEÑO, 1991: 223). El lenguaje adopta formas democráticas porque cambia la posición del ciudadano frente al poder público. Existen ante todo razones jurídicas, ya que la comprensión del Derecho conecta con los fundamentos del Estado democrático y afecta a derechos constitucionales como la dignidad de la persona, la igualdad y no discriminación, la interdicción de la arbitrariedad, la participación en los asuntos públicos, o la tutela judicial efectiva (PRIETO DE PEDRO, 1996: 114 y CONDE, 2009: 65), así como con los principios básicos de la actuación administrativa (art. 103 de la Constitución). La transparencia y la participación imponen que las relaciones entre los ciudadanos y los poderes públicos sean más cercanas y accesibles. La mejora de la eficacia comunicativa es además un factor persuasivo que facilita el cumplimiento voluntario de las normas.

En nuestro país, el derecho a comprender se menciona por primera vez en la Carta de derechos de los ciudadanos ante la Justicia de 2002, en estos términos:

"6. El ciudadano tiene derecho a que en las vistas y comparecencias se utilice un lenguaje que, respetando las exigencias técnicas necesarias, resulte comprensible para los ciudadanos que no sean especialistas en Derecho.

- Los Jueces y Magistrados que dirijan los actos procesales velarán por la salvaguardia de este derecho".

Aparte de que se circunscribe a las actuaciones judiciales, se trata de una simple proposición no de ley sin efectos normativos y no se han previsto mecanismos para hacerla efectiva. La situación contrasta con el ordenamiento procesal italiano, que reconoce un deber de motivar los actos procesales y obliga al juez a redactar "de manera clara y sintética”. Lo relevante es que estos principios de claridad y concisión, enunciados expresamente en la ley, conectan con el régimen de las costas procesales, de modo que el juez puede decidir sobre las costas teniendo en cuenta el respeto del principio de claridad y concisión.

En el ámbito del Derecho privado, el derecho a comprender se impone en relación con la autonomía de la voluntad de los contratos y con la protección del consumidor $^{47}$, mientras que en el Derecho público se reconoce sectorialmente, por

46 ¡Hasta existe un día internacional del lenguaje claro! Se celebra el 13 de octubre desde 2011, véase http://www.iplainday.org/.

47 La deficiente comprensión constituye un error del consentimiento que puede anular el contrato. Por ejemplo, la SJPI 106/2013 (ECLI:ES:JPI:2013:106) del Juzgado de Primera Instancia núm. 63 de Madrid, entra a valorar el nivel de formación del particular que había adquirido un producto financiero (FJ. 5). 
ejemplo, en la legislación procesal penal ${ }^{48}$ y en la normativa sanitaria ${ }^{49}$. Sin embargo, a pesar de su asidero constitucional (CAMPO, 2019: 67) tal Derecho no está reconocido con carácter general en la legislación administrativa básica (no lo hacía la Ley 30/1992, tampoco la Ley 39/2015), ni en ninguna otra norma transversal ${ }^{50}$.

Los lingüistas identifican criterios objetivos para establecer el nivel de legibilidad y grado de comprensión de los textos (CASSANY, 2002: 22). También el lenguaje jurídico debería ser objeto de este tipo de test y controles objetivos, debidamente validados, y, sin embargo, no están extendidos los estudios empíricos sobre el grado de comprensión de los textos jurídicos. Las iniciativas se limitan a facilitar la accesibilidad de los textos para determinados colectivos vulnerables (emigrantes, discapacitados, personas con baja formación), pero no para el ciudadano medio. Aquí nos servirían también los conocimientos de las ciencias conductuales.

Con todo, ponderando los principios de seguridad jurídica y aplicando los criterios de la interpretación jurídica, es posible dotar de eficacia aplicativa al principio de claridad del lenguaje jurídico. En el ámbito del Derecho administrativo sancionador, es evidente que la imprecisión del texto jurídico vulnera el principio de predeterminación normativa de la sanción (STC 25/2002, FJ. 4). El Tribunal Supremo ha anulado un precepto del reglamento de extranjería por considerar que era una "norma oscura que dificulta una respuesta segura a la hora de su aplicación" (STS 1678/2019, ECLI:ES:TS:2019:1678).

Desarrollamos a continuación los requisitos básicos para un Derecho comprensible: claridad (lenguaje claro), accesibilidad (lenguaje accesible) y neutralidad (lenguaje inclusivo).

${ }^{48}$ La Ley de Enjuiciamiento Criminal reconoce el derecho de toda persona a quien se atribuya un hecho punible a recibir información en un "lenguaje comprensible y que resulte accesible", adaptando la información "a la edad del destinatario, su grado de madurez, discapacidad y cualquier otra circunstancia personal" (art. 118). El Estatuto de las víctimas del delito, aprobado por Ley 4/2015, reconoce el derecho de la víctima "a entender y ser entendida" durante el proceso penal (art. 4).

49 El derecho a la información comprensible integra el derecho de la autonomía del paciente y se articula a través de instrumentos como el consentimiento informado y la hoja de información. El art. 10 de la Ley 14/1986, General de Sanidad, dispone que toda persona tiene el derecho "a que se le dé en términos comprensibles, a él y a sus familiares o allegados, información completa y continuada, verbal y escrita, sobre su proceso, incluyendo diagnóstico, pronóstico y alternativas de tratamiento". El reglamento de ensayos clínicos dispone que la información debe estar redactada "en un lenguaje sencillo y accesible al ciudadano sin especiales conocimientos científicos” (art. 48.1 del RD. 1090/2015). Una falta de información comprensible para el paciente puede acarrear responsabilidad patrimonial, si bien la jurisprudencia excluye una interpretación demasiado rígida (por todas, STS 7510/2007, FJ. 2).

50 En 2007 se constituyó la Agencia Estatal de Políticas Públicas y la Calidad de los Servicios (AEVAL), que asumía, entre otros objetivos, promover la evaluación sobre la calidad de los servicios públicos. Sin embargo, en los informes anuales se pone de manifiesto que "la claridad y comprensibilidad del lenguaje utilizado en los materiales de AEVAL, especialmente informes y guías, constituye el aspecto menos valorado por el conjunto de encuestados". Es muy llamativo que el informe CORA para la reforma de las Administraciones públicas (2013) no mencionara el lenguaje como objetivo de la simplificación administrativa. 


\subsubsection{Lenguaje jurídico claro}

El lenguaje jurídico debe ser sencillo y llano, claro, preciso y sin ambigüedades. Se debe despojar de toda afectación para aproximarse al lenguaje natural de la sociedad a la que se dirige. La claridad tiene dos vertientes: la claridad semántica (adecuado uso del lenguaje ordinario) y la claridad normativa (clara expresión de su condición de norma, su contenido y vigencia).

En relación con ello, el lenguaje del derecho, especialmente el lenguaje normativo, debe ser consistente, en el sentido que Bentham ya dio a esta palabra en el siglo XIX, como "certidumbre en la expresión" o coherencia lingüística (ZAPATERO, 2004: LV). ¡Nada menos! A pesar de la presunción de consistencia lingüística lo cierto es que este no siempre utiliza los términos en el mismo sentido y atribuye significados distintos a las mismas palabras (CENTENERA, 2012: 221 y GARCÍA AMADO, 2013: 152). La inconsistencia lingüística se extiende por obra del Derecho comunitario y también por las edades muy diferentes de las normas vigentes. Todos tenemos en mente ejemplos de términos jurídicos que no son equivalentes a efectos de una u otra norma, con contradicciones entre ellos ${ }^{51}$.

La mejora de la calidad lingüística del Derecho facilita su comprensión. La complejidad de la norma dependerá entonces de la materia regulada (fiscal, técnica, informática), pero no necesariamente del lenguaje utilizado. Sería conveniente que los juristas orientáramos nuestras investigaciones hacia la calidad lingüística y el estilo de los textos jurídicos ${ }^{52}$. No solo los aspectos semánticos son relevantes, también los puramente sintácticos, porque la estructura sintáctica de las normas condiciona su comprensión (CASSANY, 2002: 28).

En este marco se extiende el movimiento conocido inicialmente como "plain English", en Reino Unido, Estados Unidos y otros países de habla inglesa, ya convertido en movimiento internacional ("plain language movement"), con iniciativas públicas y privadas ${ }^{53}$. El movimiento del lenguaje fácil es buen ejemplo de cómo el estilo del Derecho evoluciona a lo largo de la historia y es sensible a las preocupaciones sociales. El lenguaje jurídico, y muy especialmente el lenguaje administrativo, es

51 Por ejemplo, la noción de sector público, absolutamente dúctil (BOTO, 2015), o el concepto de domicilio varía en el Derecho administrativo y en Derecho penal. La consistencia terminológica se complica cuando entra en vigor una nueva norma y no se tienen claras las reglas de transitoriedad. Así, la entrada en vigor de la Ley 40/2015 permite entender que el término "entidad pública empresarial" (art. 103) ya no alude a la misma realidad que en la derogada LOFAGE (art. 53), porque ahora se caracteriza por financiarse mayoritariamente con ingresos de mercado.

52 Del tipo del divertido trabajo que publicó CAYERO (2014: 113) sobre el lenguaje de la Ley 19/2013, de transparencia, desgranando con gracia todos sus vicios.

53 Los materiales generados en torno a este movimiento comunicativo son ya inabarcables. Me remito a la documentación disponible en la web del gobierno de los Estados Unidos, http://www.plainlanguage.gov/, a la web de referencia http://www.plainenglish.co.uk/y a la de la asociación internacional promotora del lenguaje legal sencillo, http://www.clarity-international.net/. El informe de campo "Politicas comparadas" de la CMLJ (2011) es un estupendo resumen de todas estas propuestas para conseguir un lenguaje jurídico comprensible. 
sensible ante las nuevas formas de concebir las relaciones entre los poderes públicos, instituciones y los ciudadanos, basadas en la idea de participación, calidad, transparencia y mejora de la información ${ }^{54}$.

En este proceso de simplificación inciden factores muy heterogéneos a los que se ha hecho ya referencia. Algunos son jurídicos, como el respeto de los derechos que reconoce nuestra Constitución (participación, transparencia, tutela judicial efectiva). Otros son de índole social, en concreto, los movimientos de defensa de los consumidores que arrancan en Estados Unidos en los años sesenta y setenta, y actualmente el activismo social y judicial, como apunta ATIENZA (2013: 109). Tampoco faltan razones económicas y técnicas para la simplificación del lenguaje, como la preocupación por el alto coste del papel. Las experiencias extranjeras demuestran que simplificar el lenguaje ahorra dinero y esfuerzos humanos a las instituciones públicas: el lenguaje sencillo es mucho más persuasivo, con fundamento en el principio de eficacia comunicativa (CONDE, 2009: 84) porque la confianza de los ciudadanos contribuye al cumplimiento voluntario de las normas (STRANDVIK, 2012: 131). Hay también un compromiso con la elegancia, el estilo y la belleza de la lengua (PRIETO DE PEDRO, 2016: 135).

La opacidad no es inherente al Derecho y no podemos considerar natural que solo los juristas que hablamos la misma jerga sigamos teniendo acceso al mundo jurídico. Achacar las barreras de comunicación jurídica a la complejidad intrínseca del Derecho y al hecho de ser un lenguaje técnico encierra el riesgo de perpetuar su opacidad y eximir a las instituciones de su cuota de responsabilidad (OLIVERLALANA, 2011: 340).

Es cierto que el derecho se caracteriza (o debería caracterizarse) por su precisión. La máxima precisión garantiza la coherencia del sistema, previene contradicciones y, en definitiva, preserva la seguridad en la aplicación uniforme de las normas y demás textos jurídicos. La seguridad jurídica impone utilizar conceptos unívocos y eliminar la ambigüedad, en la medida de lo posible (SAINZ MORENO, 1995: 62). La precisión del Derecho contribuye a la seguridad jurídica: no es lo mismo prescripción que caducidad, homicidio que asesinato, nulidad que anulabilidad.

Que eso sea así, sin embargo, no significa que la claridad sea enemiga del rigor (HERRERO, 2017: 11). Algunos autores temen que la simplificación del lenguaje jurídico sea contraproducente desde el punto de vista de la seguridad jurídica, en el sentido de que cuanto más específico (técnico) es el lenguaje, menos nivel de discrecionalidad se deja a la interpretación (CARRETERO y GARRIDO, 2005: 715). Se dice que el Derecho no puede renunciar a su precisión y claridad técnica, pero, a mi juicio, la revisión del estilo y la mejora de la calidad del lenguaje no suponen en modo alguno sacrificio de las formas ni de la precisión del lenguaje. Se dijo hace

54 En nuestro país, la preocupación por el lenguaje administrativo nace en los años ochenta y noventa. La aparición del Manual de estilo del lenguaje administrativo (MELA), editado por el MAP en 1990 fue calificado como "hecho sin precedentes en la vida pública española" y "un trabajo monumental que puede resultar histórico" (diario El País de 21 de junio de 1990). 
casi cincuenta años y se puede afirmar ahora: "solo una visión miope del problema" puede llevar a confundir ambos conceptos o hacer depender el rigor del empleo de frases superfluas. Al contrario, cuanto más se simplifica una forma más se la ennoblece (BLANCO DE TELLA, 1968: 88). Es cierto que la precisión es premisa de la comprensión, pero la claridad es, a su vez, condición de ambas. En realidad, el gran enemigo de la comunicación jurídica es la falta de sinceridad (ORWELL, 2017: 137); por eso el lenguaje jurídico es enrevesado y suena falso. Bastaría con aplicar rigurosamente las herramientas de la lingüística para conseguir un lenguaje jurídico más claro y, con ello, más riguroso y eficaz.

\subsubsection{Lenguaje jurídico accesible}

Lenguaje jurídico claro no es exactamente lo mismo que lenguaje accesible y legible, aunque todos están estrechamente vinculados y, de hecho, las normas suelen reconocerlos como sinónimos ${ }^{55}$. Un lenguaje jurídico accesible es aquel que está adaptado para las personas con discapacidad sensorial, física o psíquica según las reglas del llamado "diseño para todas las personas" que incluye reglas de tipo formal (tipográfico, tamaño de letra, espaciados, contraste de colores y otros) así como recomendaciones sobre aspectos lingüísticos (extensión recomendable de párrafos, longitud de oraciones, y otros $)^{56}$. El objetivo es conseguir que los textos jurídicos resulten "de lectura amable", expresión que deriva del inglés "user friendly" y de ahí el neologismo "usabilidad" que recogen algunas normas, especialmente cuando se aplica a la interacción entre personas y máquinas (MONTOLÍO, 2012: 74). Instrumentos tales como la lectura fácil, que se están extendiendo a los textos jurídicos, tanto en el plano normativo, como en los servicios públicos y el acceso a la justicia, garantizan no solo su accesibilidad y legibilidad, sino también su comprensión ${ }^{57}$. Sin embargo, no

55 Por ejemplo, la Ley 2/2010, de 1 de marzo, de derechos de los Ciudadanos con la Administración de Castilla y León, define así el principio de comprensión: "Las normas y procedimientos administrativos han de ser claros y comprensibles para los ciudadanos. Además, los medios públicos de información de los servicios han de usar un lenguaje accesible” (art. 5f). La Ley 8/2015, de 25 de marzo, de Transparencia de la Actividad Pública y Participación Ciudadana de Aragón reconoce "el principio de simplicidad y comprensión, generando una disminución progresiva de trámites mediante el rediseño de procedimientos y la optimización de recursos, así como promoviendo la utilización de un lenguaje accesible y comprensible para los ciudadanos y las ciudadanas, y la eliminación de las cargas administrativas" (art. 2.h). La Ley 4/2011, de 31 marzo, de buena administración y gobierno de Illes Balears, recoge juntos los principios de simplicidad y comprensión ("Las normas y los procedimientos administrativos tienen que ser claros y comprensibles para la ciudadanía. Además, los medios públicos de información de los servicios tienen que utilizar un lenguaje accesible" (art. $3 \mathrm{~g}$ ).

56 La ley general de derechos de personas con discapacidad y su inclusión social, aprobada por Real Decreto Legislativo 1/2013, reconoce el "derecho a la libre toma de decisiones" y para ello es imprescindible que la información y el consentimiento se presten en formatos adecuados, de manera que les resulten accesibles y comprensibles (art. 6.2).

57 La lectura fácil es una técnica de redacción que permite acceder a los textos jurídicos a personas con dificultades de comprensión lectora a partir de las directrices internacionales de Inclusion Europe y de la IFLA, que promueven una simplificación de textos con el objetivo de hacerlos accesibles a toda la 
estamos todavía ante un Derecho que se pueda exigir ante los poderes públicos o los tribunales, como confirma la STSJ de Madrid núm. 9043/2018 al negar el derecho del reclamante a que la administración le ofreciese los ejercicios de un procedimiento selectivo de acceso al empleo público en lectura fácil (ECLI:ES:TSJM:2018:9043, FJ. 6).

\subsubsection{Lenguaje juridico inclusivo}

El lenguaje jurídico debe ser neutral en cuanto al género, es decir, inclusivo, no discriminatorio y no sexista.

El principio constitucional de igualdad se extiende así a la creación, la interpretación y la aplicación del Derecho y el lenguaje jurídico se "feminiza" en palabras de CAZORLA (2007: 128). El esfuerzo por evitar el "androcentrismo léxico" está dando muchos quebraderos de cabeza a nuestros legisladores, jueces y administraciones públicas (BRIZ, 2011), que editan manuales, prontuarios y códigos de estilo sobre lenguaje jurídico no sexista. En la comunidad jurídica el tema se aborda con escepticismo e ironía, cuando no críticamente, abrumados ante una suerte de dirigismo político que impone — denuncian - un lenguaje alejado de los usos sociales y de las reglas gramaticales. Se reprocha especialmente el empeño por erradicar el uso del masculino genérico en los textos jurídicos ${ }^{58}$.

ciudadanía. Aparece en el listado de formas de comunicación accesible de la Convención Internacional de Derechos de las Personas con Discapacidad (ONU, 2006). Hasta ahora, la única mención directa en la legislación española era la Ley del Libro de 2007 (Disposición Adicional tercera) y han sido las comunidades autónomas las que más han regulado la lectura fácil. Por ejemplo, la Ley 13/2014, de accesibilidad de Cataluńa, incluye la lectura fácil como obligación para proveedores de servicios de uso público (art. 26), para las administraciones públicas (art. 33) y en la educación (art. 32). El BOA núm. 70, de 10 de abril de 2019, publica en un boletín oficial, por primera vez en nuestro país, una ley en documento de lectura fácil.

En el ámbito de la administración de justicia, algunas iniciativas aisladas están potenciando la redacción de escritos procesales en lenguaje fácil cuando están implicadas personas con discapacidad, con el antecedente de la sentencia de la corte suprema mexicana de 2013 (caso "Ricardo Adair"). La sentencia del juzgado contencioso-administrativo núm. 1 de Oviedo núm. 20/2019, de 7 de febrero, vincula las dificultades de comprensión de una persona con discapacidad con una eventual vulneración de su derecho a la tutela judicial efectiva (FJ. 3), y es de las pocas que se han redactado en formato de lectura fácil.

58 Un buen ejemplo de ello en la STSJ CL 4300/2013 - ECLI:ES:TSJCL:2013:4300, sobre la posible utilización de un lenguaje sexista en la ordenanza municipal de convivencia ciudadana de Valladolid, impugnada por una serie de asociaciones vecinales, ONGs y sindicatos. La sala afirma, en primer lugar, que los criterios establecidos en las normas para conseguir un lenguaje no sexista "no son más que criterios, recomendaciones u objetivos para los poderes públicos y demás interpelados, pero de tal extremo no cabe inferir que una norma sea radicalmente nula, por no explicitar el femenino junto al masculino". En segundo lugar, acude a las reglas gramaticales para recordar que "en idiomas como el español, el género gramatical tiene por forma no marcada el masculino de los sustantivos y adjetivos, siendo incluyente frente al femenino marcado. (...) Si, por ejemplo, la LOPJ habla de los jueces y magistrados, sin duda una correcta exégesis permite entender que incluye a los jueces, juezas, magistrados y magistradas, mientras que cuando la propia LOPJ establece disposiciones para las juezas (art. 360 bis), inequívocamente está excluyendo a los jueces" (FJ. 5). Sin embargo, el empleo del sustantivo en 
Pero los excesos de ciertas reivindicaciones, que hacen farragosos y repetitivos los textos jurídicos, no deben ocultar la necesidad de luchar para que el lenguaje sea cada vez más neutral, algo absolutamente compatible con la seguridad jurídica (BALAGUER, 2008: 71). Tampoco debería oponerse como excusa que "la lengua no es sexista, sino que lo es la sociedad" (SÁNCHEZ LOBATO, 2006: 38), porque no es verdad: el lenguaje sí es sexista, como puede ser discriminatorio o autoritario. El lenguaje no es aséptico y es un importante motor de transformación social, una herramienta para eliminar estereotipos. Como advierte DEL VALLE (2016: 20), las disputas sobre cuestiones lingüísticas no son solo formales, ya que lo lingüístico no existe al margen de lo social y lo político. En cualquier caso, coincido en que no debemos quedarnos en el simple plano formal, acotado al lenguaje inclusivo, sino que hay que avanzar por el camino del impacto de género sustantivo o de fondo, que es una herramienta para mejorar la calidad del Derecho (NOGUEIRA, 2019: 322) ${ }^{59}$.

\subsection{Lenguaje jurídico universal}

Según las tesis del relativismo lingüístico, el lenguaje —el jurídico también— es un producto cultural condicionado por el entorno y el hecho diferenciador por excelencia. Esta interdependencia entre lenguaje y cultura es fácil de explicar: el lenguaje es parte del comportamiento humano y la cultura se transmite mediante el lenguaje (ACERO, BUSTOS, QUESADA, 2001: 254). Pero la sociedad actual está fuertemente globalizada, económica, tecnológica y culturalmente, y esta realidad conduce inevitablemente a la integración de los lenguajes jurídicos.

Una sociedad globalizada requiere unas reglas de juego comunes, es decir, un lenguaje jurídico global. En una sociedad globalizada el derecho tiende a actuar como esperanto o lenguaje universal y se considera una herramienta eficaz para resolver conflictos (ROSELLI, 2016: 4) ${ }^{60}$. Ihering ya buscaba un alfabeto jurídico integrado por elementos simples que permitieran generar una infinita diversidad de proposi-

su forma femenina no garantiza que "inequívocamente" la norma excluya a los varones. Una serie de sentencias del tribunal constitucional (por todas, SSTC 253/1988, de 20 de diciembre y 102/1992, de 25 junio) reconocieron el derecho del viudo a obtener la pensión de viudedad que había solicitado, a pesar de la literalidad de la ley que sólo mencionaba "las viudas" (FJ. 7).

La polémica tenía que alcanzar a la mismísima Real Academia de la Lengua Española, con disputas internas - mediáticas - que se remontan al conocido texto de 2012 firmado por Ignacio Bosque y otros veinticinco académicos de la lengua, una bofetada contra las guías de lenguaje no sexista elaboradas por diversas instituciones públicas.

59 La STS 4087/2018, ECLI:ES:TS:2018:4087, dio un paso de gigante al anular un plan de ordenación urbana por falta de informe de impacto de género.

${ }^{60}$ Un ejemplo cercano de este lenguaje normativo universal es el de los signos y las señales de tráfico, un verdadero lenguaje universal que arranca de la Convención sobre Circulación Vial de 1968 (conocida como "Convención de Viena") en el seno de la ONU. Paradójicamente, el desarrollo de nuevas tecnologías en el sector de la señalización de tráfico, desde los paneles variables introducidos en los años ochenta, está minando la internacionalización de los signos de tráfico al introducir letras y palabras en un lenguaje que hasta ahora era eminentemente icónico y simbólico. 
ciones y supuestos jurídicamente relevantes. Aunque en este proceso se enfrentan dos tendencias contrapuestas, que en palabras de MARINA (1998: 22) son "la globalización y la vuelta al terruño", es evidente de que los ordenamientos jurídicos de los distintos países (al menos los europeos y occidentales, los del "primer mundo") sufren un proceso de transformación que los hace cada vez más parecidos ${ }^{61}$.

Para no desviar nuestra atención de la pragmática del lenguaje jurídico, tan solo me centraré en tres aspectos relacionados con la cuestión lingüística: los problemas de traducción, el impacto del inglés como lengua universal y la codificación como instrumento para la armonización lingüística:

- La traducción de los textos jurídicos constituye una parte esencial de la metodología del Derecho comparado, primer paso en la búsqueda de un lenguaje jurídico universal (DE LA SIERRA, 2004: 102). La traducción es insoslayable en el estudio de lenguajes jurídicos diferentes; pero aquí no nos sirve la traducción radical, es decir, la traducción de una lengua a la que se arriba por primera vez y acerca de cuya cultura se carece de información (ACERO, BUSTOS, QUESADA, 2001: 246) ${ }^{62}$. Un jurista español no puede adentrarse en un ordenamiento jurídico si sólo conoce la lengua extranjera. Para conseguir una buena traducción es necesario comprender la forma en que se vertebra el ordenamiento jurídico y las leyes en un país determinado, y esta tarea precisa tiempo y muchos escollos para el traductor no jurista aunque tenga buen conocimiento de la lengua ${ }^{63}$. Ya intuye VAQUER (2014: 3010) que los conceptos traídos de otros ordenamientos jurídicos o de otras disciplinas científicas no pueden ser recibidos por el simple expediente de su traducción, sino que requieren un proceso de transposición. Además, resulta muy difícil transferir el pensamiento abstracto de un lenguaje a otro porque depende, en buena medida, del lenguaje en que ha sido formulado. Conocer los principios de la filosofía del lenguaje nos ayuda a aplicar mejor el método del derecho comparado y conocer las dificultades derivadas de la importación de términos extranjeros (DE LA SIERRA, 2004).

${ }^{61}$ Como se ha dicho, la globalización esconde un problema conceptual y terminológico (DARNACULLETA, 2016: 34). En todo caso, las instituciones internacionales y la Unión Europea, en particular, resultan un excelente campo de pruebas porque en su seno conviven ordenamientos jurídicos expresados en diferentes lenguas, que responden a diferentes culturas y evoluciones históricas. La UE realiza constantemente esfuerzos de armonización de términos jurídicos para que se apliquen e interpreten con el mismo significado y cuenta con un servicio propio de juristas lingüistas. La Directiva, en tanto que mecanismo propio para la armonización jurídica, tiene efectos indirectos en la armonización lingüística, si bien no siempre con buenos resultados como destaca FONT (2006: 105).

62 Las investigaciones sobre la traducción automática de los ordenadores ocuparon a los filósofos en los años 1948-1964 con el nacimiento de los primeros ordenadores (ACERO, BUSTOS, QUESADA, 2001: 142). Se trataba de conseguir que un ordenador fuera capaz de traducir de una lengua natural a otra, pero las investigaciones se saldaron con un fracaso estrepitoso, porque para traducir no solo hay que tener conocimientos lingüísticos, sino también empíricos.

63 Existen estudios de campo específicos sobre cuestiones terminológicas en la traducción jurídica, que desgranan las dificultades que encuentra el traductor no jurista desde el punto de vista terminológico y conceptual, de los que es imposible hacer una referencia completa aquí (por todos, GINÉS AGUILAR, 1997). La comunicación entre juristas y especialistas en lengua y traducción no es fluida y ambos se contemplan mutuamente con desconfianza (CARRETERO, GARRIDO, 2005: 713). 
- El marco de referencia para adoptar ese derecho universal parece ser el del Estado con mayor capacidad para imponerse como potencia — política, económica, cultural, tecnológica...- en cada momento histórico (ESTEVE PARDO, 2010: 295). Y por eso el inglés se ha convertido en un lenguaje universal que se extiende como lengua vehicular en el derecho no solo entre la comunidad científica (por razones que tienen mucho que ver con el prestigio, la promoción profesional, el impacto de las citas, etc.) sino también entre los juristas prácticos. La expansión del inglés como lengua vehicular en la divulgación jurídica y también en la enseñanza universitaria no está exenta de problemas. En Holanda, donde buena parte de la docencia universitaria se imparte en inglés, hay estudios que afirman que el uso de una lengua distinta de la materna impide alcanzar los mismos matices de pensamiento y la capacidad de abstracción que sí permite la lengua materna, así que el resultado termina siendo una especie de inglés internacional empobrecido ${ }^{64}$. La ciencia conductual nos enseña que el uso de una lengua extranjera distinta a la propia hace que usemos más el sistema cognitivo reflexivo y menos el automático (SUNSTEIN, 2015).

- Excluyendo los glosarios o diccionarios orientados a la traducción jurídica ${ }^{65}$, la codificación es una herramienta para la aproximación de ordenamientos jurídicos, aunque no sea suficiente, por sí sola, para alcanzar un lenguaje jurídico universal. Ante instituciones, lenguaje y conceptos jurídicos tan desiguales la tarea codificadora se hace complicadísima (SAINZ MORENO, 1995: 57). Quizás por eso se dice que la codificación ha fracasado en el Derecho público (MUNOZ MACHADO, 2005: 27), aunque no han faltado loables esfuerzos en esta dirección ${ }^{66}$.

\section{CONCLUSIONES}

El propósito de este trabajo era diseñar una radiografía del lenguaje jurídico. El derecho es un lenguaje y, como tal, se puede abordar con un enfoque lingüístico. Tradicionalmente los juristas hemos prestado atención al lenguaje en nuestra tarea

${ }^{64}$ Como lamenta el profesor de filosofía de la Universidad de Rotterdam, G. Groot (entrevista en el diario El País, de 31 de marzo de 2016).

${ }^{65}$ La elaboración de glosarios o diccionarios de términos jurídicos traducidos a distintas lenguas y acompañados de la correspondiente definición es otro instrumento para conseguir la armonización lingüística. Como ejemplo, el dirigido por R. DOMINGO (dir.), (2006).

Los lingüistas no se ponen de acuerdo acerca de si existen o no universales lingüísticos que formarían un metalenguaje universal con el que podrían definirse las palabras en cualquier lengua, porque el lenguaje humano es esencialmente borroso, como lo es el pensamiento humano. Es cierto que existe el riesgo de petrificación del vocabulario jurídico, parcialmente subsanado por la inmediatez de las nuevas tecnologías que permiten una constante adaptación (DE LA SIERRA, 2004: 118). Con todo, y siendo conscientes de que no siempre ofrecen un tratamiento satisfactorio de la equivalencia jurídica (CUNILLERA, 2011: 67), estos glosarios y diccionarios son un instrumento útil para los juristas.

${ }^{66}$ En 2015 se elaboró el Código ReNEUAL de procedimiento administrativo de la UE, en cuya elaboración se tuvieron muy en cuenta los aspectos lingüísticos (MIR y otros, 2015: 30). En efecto, su redacción final siguió un necesario proceso de "revisión de la compatibilidad del lenguaje para evitar el uso de conceptos que perderían su sentido en la traducción y revisión del inglés" que ha sido el idioma empleado en su redacción. 
hermenéutica y sistemática (art. 3.1 del Código Civil), pero no tanto como vehículo de comunicación y narración del Derecho. El giro lingüístico permite aproximarse a cuestiones esenciales para el Derecho como los aspectos emotivos de la comunicación jurídica, el uso persuasivo del lenguaje y el impacto del contexto sociopolítico. En definitiva, el método lingüístico es un instrumento útil para la ciencia jurídica en sus dimensiones léxica, semántica y pragmática, ya que todos estos planos se retroalimentan. Si nos tomamos en serio el lenguaje podemos conseguir una mayor racionalidad jurídica.

El enfoque léxico y semántico permite entender cómo se exteriorizan los conceptos jurídicos a través del lenguaje, su significado y evolución. No estamos ante simple logomaquias: que una palabra esté o no en los textos jurídicos tiene vital importancia porque el Derecho tiene esa dimensión demiúrgica, no es neutro, es un arma de poder. Pensemos, por ejemplo, en el cúmulo de textos jurídicos que incluyen términos como "sostenibilidad", "transparencia", "memoria histórica", "seguridad jurídica" o "inclusividad" que moldean la realidad de manera sutil y orientan las conductas de los ciudadanos. En especial la metodología conceptual facilita al jurista herramientas para detectar las capas de los términos jurídicos y la adecuación entre significados y significantes. El hecho de que las palabras sean las mismas no significa que los conceptos jurídicos hayan permanecido iguales o, al contrario, nuevos términos jurídicos pueden disimular un vacío conceptual. Al respecto, observo tendencias contradictorias donde conviven la proliferación de neologismos con cierto conservadurismo léxico.

El enfoque pragmático, por su parte, resulta imprescindible para adaptar el lenguaje jurídico a su contexto y favorecer la comunicación. La aproximación a esta metodología exige establecer distintos niveles de textos jurídicos y no tratarlos todos de la misma manera. He insistido en que el lenguaje es un instrumento para la dirección de conductas y que, como nos enseñan las ciencias conductuales, los textos jurídicos podrían tener efectos muy diferentes en función de la fórmula lingüística empleada. Por otro lado, el giro lingüístico consolida la necesidad de que el lenguaje jurídico sea comprensible para sus destinatarios: un mínimo de limpieza del lenguaje es requisito para cualquier diálogo. Estoy convencida de que la claridad es una exigencia del Estado social y democrático de Derecho y que fortalece la confianza en las instituciones y los mecanismos de control social. Sin embargo, a pesar de su amplísima repercusión social, el lenguaje jurídico fracasa comunicativamente y ello genera importantes costes no solo económicos, sino también sociales.

En fin, la perspectiva lingüística del Derecho abre otros temas para investigaciones futuras que dejo apuntados en mi trabajo, como el impacto de la imagen o de la inteligencia artificial en el lenguaje jurídico, el diseńo legal, la expresión oral del Derecho o el lenguaje jurídico universal. 


\section{REFERENCIAS BIBLIOGRÁFICAS}

Juan José ACERO, Eduardo BUSTOS y Daniel QUESADA, Introducción a la filosofía del lenguaje, 5a ed., Madrid: Cátedra, 2001.

Enrique ALCARAZ y Brian HUGUES, El español jurídico, 2.a ed., Barcelona: Ariel Derecho, 2002.

Robert ALEXY, Theorie der juristischen Argumentation: Die Theorie des rationalen Diskurses als Theorie der juristischen Begründung, Frankfurt am Main: Surkamp, 1983. Citamos por la edición al español a cargo de Manuel ATIENZA e Isabel ESPEJO, Teoría de la argumentación jurídica: la teoría del discurso racional como teoría de la fundamentación jurídica, 2. ${ }^{a}$ ed., Madrid: Centro de Estudios Políticos y Constitucionales, 2008.

Donatella ANTELMI, "Vaghezza, definizioni e ideologia nel linguaggio giuridico", en Giuliana GARZONE y Francesca SANTULLI (eds.): Il linguaggio giuridico. Prospetive interdisciplinari, Milán: Giuffrè Editore, 2008, pp. 89 a 115.

Manuel ATIENZA, Podemos hacer más. Otra forma de pensar el Derecho, Madrid: Pasos Perdidos, especialmente el prólogo (pp. 9 a 29), 2013.

John L. AUSTIN, How to Do Things with Words: The Williams James Lectures Delivered at Harvard University in 1955, ed. de J. O. URSOM, Oxford: Clarendon Press, 1962. Citamos por edición en español Palabras y acciones: Cómo hacer cosas con palabras, Barcelona: Paidós, 1982.

María Luisa BALAGUER, "Género y lenguaje: presupuestos para un lenguaje jurídico igualitario", en Revista de Derecho Politico, núm. 73, 2008, pp. 73-100.

José Ma. BAÑO, "El recurso administrativo como ejemplo de la inercia autoritaria del derecho público español", en Fernando LÓPEZ RAMÓN (coord.), Las vías administrativas de recurso a debate: Actas del XI Congreso de la Asociación Española de Profesores de Derecho Administrativo, Madrid: INAP, 2016, pp. 496-518.

- "La formación básica del ciudadano y el mundo del derecho. Crítica lingüística del lenguaje judicial”, Revista de Llengua i Dret, núm. 25, 1996, pp. 51-72.

— "El lenguaje forense: estructura y estilo", Estudios de Derecho Judicial, núm. 32, Ejemplar dedicado a: "Lenguaje forense", 2000, pp. 35-76.

"El lenguaje judicial del futuro", Estudios Jurídicos, 2011.

Harold J. BERMAN, Law and Language. Effective Symbols of Community, Cambridge: Cambridge University Press, 2013.

José BERMEJO, El declive de la seguridad jurídica en el ordenamiento plural, Discurso de ingreso en la Academia Aragonesa de Jurisprudencia y Legislación, 2005.

Pablo BIEGER, "El abogado", LUIS Ma DÍEZ-PICAZO (coord.), El oficio de jurista, Madrid: Siglo XXI de Espańa Editores, 2006, pp. 17-56.

Luis BLANCO DE TELLA, "Reflexiones sobre el lenguaje administrativo", Documentación Administrativa núm. 122, 1968, pp. 73-88.

Anabel BORJA: "Los géneros jurídicos”, en Enrique ALCARAZ, José MATEO y Francisco YUS (eds.), Las lenguas profesionales y académicas, Barcelona: Ariel, 2007, pp. 141-154.

Ignacio BOSQUE, "Sexismo lingüístico y visibilidad de la mujer", en http://www.rae.es/sites/default/ files/Sexismo_linguistico_y_visibilidad_de_la_mujer_0.pdf, 2012.

Alejandra BOTO, "La noción de sector público institucional: aplauso, crítica y desconcierto", Documentación Administrativa. Nueva Época, núm. 2, 2015.

Antonio BRIZ (coord.), Guía de comunicación no sexista, Madrid: Instituto Cervantes-Santillana Ediciones Generales, 2011.

Óscar BUENAGA: Metodología del razonamiento jurídico-práctico. Elementos para una teoría objetiva de la argumentación jurídica, Madrid: Dykinson, 2016.

José CALVO, Desarrollo y narración. Materiales para una teoría y crítica narrativa del Derecho, Barcelona: Ariel Derecho, 1996.

Luciana CALVO, Introducción al estudio del lenguaje administrativo. Gramática y textos, Biblioteca Hispánica Románica, Madrid: Gredos, 1980.

Juan Carlos CAMPO, "El futuro de la modernización del lenguaje jurídico", Revista del Ministerio Fiscal, núm. 8, 2019, pp. 58-71. 
Miguel Ángel CAMPOS, "El lenguaje de las ciencias jurídicas. Nuevos retos y nuevas visiones”, en Enrique ALCARAZ, José MATEO y Francisco YUS (eds.), Las lenguas profesionales y académicas, Barcelona: Ariel, 2007, pp. 155-165.

Juan Ramón CAPELLA, El derecho como lenguaje. Un análisis lógico, Barcelona: Ariel, 1968.

Paolo CAPPELLINI, Storie di concetti giuridici, Torino: Giappichelli, 2010.

Cristina CARRETERO, "Reflexiones acerca de la expresión y la comunicación del derecho por los juristas españoles en la actualidad", Revista Aranzadi Doctrinal, núm.1, 2015, pp. 1-14.

Cristina CARRETERO y Julio Carlos FUENTES, "La claridad del lenguaje jurídico", Revista del Ministerio Fiscal núm. 8, 2019, pp. 5-40.

Cristina CARRETERO y Ramón GARRIDO, “Derecho y lenguaje: perspectivas interdisciplinares”, en $\mathrm{M}^{\mathrm{a}}$ Luisa ROMANA (ed.), Actas del II Congreso Internacional de la Asociación Ibérica de Estudios de Traducción e Interpretación, Madrid, 9-11 de febrero de 2005, Madrid, 2005, pp. 713-727.

Daniel CASSANY, La cocina de la escritura, 10a ed., Barcelona: Anagrama, 2002.

Heraclia CASTELLÓN: El lenguaje administrativo. Formas y uso, Colección Monografías de Lengua y Literatura, Granada: Editorial La Vela, 2001.

"Empleos actuales del lenguaje administrativo. Enfoques recientes de estudio", Revista de Llengua i Dret, núm. 46, 2006, pp. 181-203.

Antonio CAYERO, "El lenguaje jurídico administrativo y la ley de transparencia", Revista CEFLEGAL, núm. 167, 2014, pp. 113-166.

Luis María CAZORLA, El lenguaje jurídico actual, 1. a ed., Cizur Menor: Thomson Aranzadi, 2007.

"Consideraciones sobre el lenguaje jurídico actual", en ob. col. Historia y Filosofía Política, Jurídica y Social. Estudios en homenaje al profesor Gregorio Peces-Barba, vol. 2, Madrid: Dykinson, 2008, pp. 331-354.

Fernando CENTENERA, "La consistencia en el lenguaje de las normas: hacia una propuesta coherente”, Revista Ius et Praxis, núm. 2, 2012, pp. 219-240.

Agustí CERRILLO: "El impacto de la inteligencia artificial en el derecho administrativo ¿Nuevos conceptos para nuevas realidades técnicas?", Revista General de Derecho Administrativo, núm. 50, 2019.

Paul CHYNOWETH, "La investigación jurídica: aspectos epistemológicos, metodológicos y culturales", Administración y Ciudadanía. Revista da Escola Galega de Administracion Publica, vol. 3, 2008, pp. 29-45.

Jesús CONDE, Lenguaje administrativo y Derecho. El lenguaje como aspecto de la actividad administrativa, Cizur Menor: Aranzadi, 2009.

Montserrat CUNILLERA, "Dret comparat i traducció jurídica: el Dret real de les servituds en francès, català i espanyol", Revista de Llengua i Dret, núm. 56, 2011, pp. 65-81.

Mercè DARNACULLETA, "El derecho administrativo global. ¿Un nuevo concepto clave del Derecho administrativo?", Revista de Administración Pública, núm. 199, 2016, pp. 11-50.

Susana DE LA SIERRA, Una metodología para el derecho comparado europeo, Cuadernos Civitas, Madrid: Civitas, 2004.

Rafael DE MENDIZÁBAL, "Palabras, palabras, palabras" prólogo a Ángel MARTÍN DEL BURGO, El lenguaje del Derecho, Barcelona: Bosch, 2000, pp. 1-4.

Jesús DELGADO, El vigor de las leyes: el campo semántico validez en el Diccionario de autoridades, Zaragoza: Prensas Universitarias de Zaragoza, 2013.

José DEL VALLE (ed.), Historia politica del español. La creación de una lengua, Madrid: Aluvión Editorial, 2016.

Guy DEUTSCHER, El prisma del lenguaje. Cómo las palabras colorean el mundo, Barcelona: Ariel, 2011.

Francisco J. DÍAZ REVORIO, "El lenguaje de las normas, las normas del lenguaje: sobre la corrección del lenguaje normativo", Revista Española de la Función Consultiva núm. 22, 2014, pp. 73-112.

Silvia DÍEZ SASTRE, "La formación de conceptos (dogmáticos) en el Derecho público", Revista Jurídica de la Universidad Autónoma de Madrid, núm. 31, 2015, pp. 105-135.

La formación de conceptos en el Derecho Público, Madrid: Marcial Pons, 2018.

Luis Ma . DÍEZ-PICAZO, "Los preámbulos de las leyes. En torno a la motivación y la causa de las disposiciones normativas", Anuario de Derecho Civil, vol. 45, núm. 2, 1992, pp. 501-534.

(coord.), El oficio de jurista, Madrid: Siglo XXI de Espańa Editores, 2006. 
Gabriel DOMÉNECH, "Se alquilan habitaciones", en almacendederecho.org/, 2016 (recuperado: 11/07/2019).

Rafael DOMINGO (dir.), Principios de derecho global. 100 reglas y aforismos jurídicos comentados, 2. ${ }^{\mathrm{a}} \mathrm{ed}$. rev., The Global Law Collection, Cizur Menor: Aranzadi, 2006.

Carles DUARTE, "Els llenguatges d'especialitat", Revista de Llengua i Dret, núm. 14, 1990, pp. 93-109.

—"El llenguatge administratiu i jurídic: la necessitat d'un nou pas endavant", Revista de Llengua i Dret, núm. 38, 2002, pp. 13-17.

—"El lenguaje jurídico catalán, entre la tradición y la modernidad", en Estrella MONTOLÍO (ed.), Hacia la modernización del discurso jurídico, Barcelona: Universidad de Barcelona, 2012, pp. 125130.

Birgit ECKART, Fachsprache als Kommunikationsbarriere? Verständigungsprobleme zwischen Juristen und Laien, Wiesbaden: DUV-Deutscher Universitäts-Verlag, 2000.

Antonio EMBID, "Norma, economía y lenguaje en el derecho de la crisis económica. El control judicial de la actividad administrativa en la economía. Algunas reflexiones", Documentación administrativa. Nueva época, núm. 1, enero-diciembre 2014.

Daniel ENTRENA, Eficacia Administrativa (Eficiente) y Plenitud de los Derechos Sociales, Valencia: Tirant lo Blanch, 2017.

Lars ERIKSEN y Karin LUTTERMANN, Juristische Fachsprache. Kongressberichte des 12th European Symposium on Language for Special Purposes, Brixen/Bressanone 1999, Münster: Lit VerLag, Münster, 2002.

Ma Victoria ESCANDELL, Introducción a la pragmática, Barcelona: Ariel, 2011.

José ESTEVE, "La recepción en la Europa continental del Derecho de la regulación de la economía", Revista de Administración Pública, núm. 183, 2010, pp. 295 - 307.

Javier EZQUIAGA, "Concepto, valor normativo y función interpretativa de las exposiciones de motivos y los preámbulos", Revista Vasca de Administración Pública, núm. 20, 1988, pp. 27-49.

Tomás-Ramón FERNÁNDEZ, Arbitrario, arbitraire, arbitrary. Pasado y presente de un adjetivo imprescindible en el discurso jurídico, Madrid: Iustel, 2016.

Maria FONT, "Qüestions terminològiques en la transposició de Directives sobre Dret contractual europeu: la perspectiva de l'ordenamient jurídic espanyol", Revista de Llengua i Dret, núm. 46, 2006, pp. 103-128.

Michel FOUCAULT, Les mots et les choses. Une archéologie des sciences humaines, Paris: Gallimard, 1966. Citamos por la edición en español Las palabras y las cosas. Una arqueología de las ciencias humanas, 3. a ed., Madrid: Siglo XXI de España Editores, $3^{a}$ ed., 2005.

Vitorio FROSINI, La letra y el espiritu de la Ley, Barcelona: Ariel Derecho, 1995.

Ángel GARCÉS, "Algunas consideraciones sobre la decadencia del principio de legalidad en el Derecho español", Revista Vasca de Administración Pública núm. 103, 2015, pp. 219-221.

Juan Antonio GARCÍA AMADO, Razonamiento jurídico y argumentación: nociones introductorias, León: EOLAS ediciones, 2013.

Ma Ángeles GARCÍA y Fernando POLANCO, "Solemnidad, formalidad e (in)inteligibilidad. La selección léxica y la normativa lingüística en la redacción de documentos judiciales", en Estrella MONTOLÍO (ed.) Hacia la modernización del discurso jurídico, Barcelona: Universidad de Barcelona, 2012, pp. 195-209.

Eduardo, GARCÍA DE ENTERRÍA, La lengua de los derechos. La formación del derecho público europeo tras la revolución francesa, Madrid: Alianza Editorial, 1994.

"Prólogo" en Luis CAZORLA, El lenguaje jurídico actual, 1. a ed., Cizur Menor: Thomson Aranzadi, 2007, pp. 15-18.

Giuliana GARZONE y Francesca SANTULLI, Il linguaggio giuridico. Prospetive interdisciplinari, Milano: Giuffrè Editore, 2008, pp. 285-303.

John GIBBONS, Forensic linguistics: an introduction to language in the justice system, Oxford: Blackwell, 2003.

—"Taking legal language seriously", en John GIBBONS y otros (eds.), Language in the Law, Nueva Delhi: Orient Longman, 2004, pp.1-17.

Pedro GINÉS, Introducción a la traducción jurídica, Granada: Comares, 1997. 
Marga GÓMEZ BORRÁS, "La nueva retórica y el nuevo lenguaje jurídico”, Revista Jurídica de Navarra, núm. 39, 2005, pp. 97-138.

Alberto GÓMEZ FONT, "Abogacía y corrección idiomática”, Revista de Llengua i Dret, núm. 51, 2009, pp. 187-200.

Samuel GONZÁLEZ CASADO, "Errores sintácticos en los textos jurídicos: la calidad editorial por puntos", Revista Jurídica de Castilla y León, núm. 7, 2005, pp. 235-260.

Luis GRACIA MARTÍN, "Construcción arbitraria y quebranto de conceptos jurídicos fundamentales en el sociologismo y la política criminal libres de empirismo y de dogmática jurídica", Revista General de Derecho Penal, núm. 26, 2016, pp. 1-105.

Ricardo GUASTINI, La sintaxis del Derecho, Madrid: Marcial Pons, 2016.

Enrique P. HABA, El espejismo de la interpretación literal. Encrucijadas del lenguaje jurídico, San José: Editorial Blamarán, 2003.

Jürgen HABERMAS, Theorie des kommunikativen Handelns, Frankfurt: Surkamp, 1981. Citamos por la edición española Teoría de la acción comunicativa, 4 . $^{\mathrm{a}}$ ed. rev., Madrid: Taurus, 1987.

Juan F. HERRERO, "La incertidumbre del proceso civil", Revista General de Derecho Procesal, núm. 42, 2017, pp. 1-28.

Víctor-José HERRERO, Diccionario de expresiones y frases latinas, 3. a ed., Madrid: Gredos, 1995.

Antonio HERNÁNDEZ-GIL, El lenguaje del Derecho administrativo, Madrid: INAP, 1986.

Paolo HERITIER, "Law and Image: towards a theory of nomograms", en Anne WAGNER y Richard K. SHERWIN (eds.), Law, Culture and Visual Studies, Springer Verlag, 2014, pp. 25-48.

Mario HERNÁNDEZ RAMOS y Volker HEYDT, "Legislative language and style", en Ulrich KARPEN y Helen XANTHAKI (eds.), Legislation in Europe: A Comprehensive Guide For Scholars and Practitioners, Oxford y Portland: Hart Publishing, 2017, pp. 129-143.

Luis Alberto HERNANDO, El lenguaje jurídico, Serie español práctico, Madrid: Verbum, 2003.

Christopher Mark HUTTON, "Linguistic Landscape, Law and Reflexive Modernity", en Anne WAGNER y Richard K. SHERWIN (eds.), Law, Culture and Visual Studies, Springer Verlag, 2014, pp. 599-613.

Victoria ITURRALDE, Interpretación literal y significado convencional. Una reflexión sobre los límites de la interpretación jurídica, Madrid: Marcial Pons, 2014.

Matthias KLATT, Hacer el derecho explícito. Normatividad semántica en la argumentación jurídica, Madrid: Marcial Pons, 2017.

Reinhart KOSELLECK, Vergangene Zukunft. Zur Semantik geschichtlicher Zeiten, Frankfurt: Surkamp, 1979. Citamos por la edición española Futuro pasado. Para una semántica de los tiempos históricos, Barcelona: Paidós, 1993.

Zeitschichten. Studien zur Historik, Frankfurt: Surkamp, 2000. Citamos por la traducción española de Elías PALTI, Los estratos del tiempo: estudios sobre la historia, Barcelona: Paidós, 2001.

George LAKOFF, No pienses en un elefante. Lenguaje y debate politico, Madrid: Editorial Complutense, 2004.

Francisco J. LAPORTA, “El lenguaje y la ley”, Revista Española de la Función Consultiva, núm. 6, 2006, pp. 97-110.

Emilio LLEDÓ, Filosofía y lenguaje, Esplugas de Llobregat: Ariel,1970. Citamos por la 1.a ed. en Biblioteca de Bolsillo, Barcelona: Crítica, 2008.

José LÓPEZ, Lenguaje, normas y sistema jurídico, Madrid: Tecnos, 2012.

Anna LÓPEZ SAMANIEGO, "Documentos profesionales con destinatarios no expertos. El empleo de los mecanismos referenciales en la sentencia del 11M", Revista signos: estudios de lingüística, núm. 72, 2010, pp. 99-123.

Pablo LORENZANO, "La filosofía de la ciencia y el lenguaje: relaciones cambiantes, alcances y límites", Arbor: Ciencia, pensamiento y cultura, núm. 747, 2011, pp. 69-80.

José Antonio MARAVALL, Estudios de la historia del pensamiento español (s. XVIII), introducción y compilación de Ma Carmen IGLESIAS, Madrid: Mondadori, 1991.

José Antonio MARINA, La selva del lenguaje, Madrid: Anagrama, 1998.

Jacinto MARTÍN, Reyes RUIZ, Juan SANTAELLA y José ESCÁNEZ, Los lenguajes especiales, Granada: Comares, 1996. pp. 1-100. 
Ángel MARTÍN DEL BURGO, El lenguaje del Derecho, Barcelona: Bosch, 2000.

Luis MARTÍN REBOLLO, "Actitudes metodológicas y escenarios nuevos. (Una reflexión sobre la postura del jurista académico ante los retos que plantean las transformaciones sociales y las nuevas tendencias)", en Marcos VAQUER, Ángel Manuel MORENO, Antonio DESCALZO (coords.), Estudios de Derecho Público en Homenaje a Luciano Parejo Alfonso, volumen I, Valencia: Tirant lo Blanch, 2018, pp. 155-173.

Manuel MARTÍNEZ BARGUEÑO, "La modernización del lenguaje administrativo", Revista de Estudios de la Administración local y autonómica, núm. 250, 1991, pp. 217-233.

Diego MEDINA (coord.), La teoría comunicacional del Derecho a examen, Cizur Menor: Civitas Thomson Reuters Aranzadi, 2017.

Aurelio MENÉNDEZ (dir.) La proliferación legislativa: un desafio para el Estado de Derecho, Madrid: Thomson Civitas, 2004.

Oriol MIR, "El concepto de Derecho administrativo desde una perspectiva lingüística y constitucional”, Revista de Administración Pública, núm. 162, 2003, pp. 47 ss.

Oriol MIR y otros (dirs.), Código ReNEUAL del procedimiento administrativo de la Unión Europea, Madrid: INAP, 2015.

Estrella MONTOLÍO, "La situación del discurso jurídico escrito español. Estado de la cuestión y algunas propuestas de mejora", en Estrella MONTOLÍO (coord.), Hacia la modernización del discurso jurídico, Barcelona: Universidad de Barcelona, 2012, pp. 65-91.

Elisa MOREU, La Administración anunciante, Cizur Menor: Thomson Aranzadi, 2005.

—-Integración de nudges en las políticas ambientales", Revista Aragonesa de Administración Pública, núm. Extra 19, 2018, pp. 451-485.

José Juan MORESO, “Lenguaje jurídico”, en Ernesto GARZÓN y Francisco Javier LAPORTA, (eds.), El derecho y la justicia, Madrid: Trotta, 1996, reimpresión 2000, pp. 105-116.

Santiago MUÑOZ MACHADO, "Prólogo" en Santiago MUÑOZ MACHADO (dir.), Diccionario de Derecho administrativo, Madrid, Iustel, 2005, pp. 17-30.

(dir.), El libro de estilo de la justicia, Barcelona: Espasa, 2017.

Horst NEUMANN-DUESBERG, Sprache im Recht, Regensberg: Münster, 1949.

Alejandro NIETO, El arbitrio judicial, Barcelona: Ariel, 2000.

Alba NOGUEIRA, "La evaluación de impacto de género, ¿̇utina o lentes lilas?", en Dolors CANALS (dir.), La evaluación de impacto normativo por razón de género. Su aplicación efectiva en las instituciones europeas y en España, Madrid: CEPC, 2019.

Karl OLIVECRONA, "Legal Language and Reality" en Ralph A. NEWMAN (ed.), Essays in Honor of Roscoe Pound, Indianapolis: The American Society for Legal History, 1962. Citamos por la edición en español Lenguaje jurídico y realidad, Buenos Aires: Centro Editor de América Latina, 1968.

Manuel OLIVENCIA, "Sobre una preceptiva del lenguaje jurídico", Boletín de la Real Academia Sevillana de Buenas Letras: Minervae Baeticae, núm. 27, 1999, pp. 9-23.

Daniel OLIVER-LALANA, Legitimidad a través de la comunicación. Un estudio sobre la opacidad y la publicidad del derecho, Granada: Comares, 2011.

Andrés OLLERO, "Coloquio", en. José Luis ALBÁCAR (coord.), Reflexiones sobre la justicia en España, Madrid: Fundación por la Modernización de España, Madrid, 1999, pp. 105-107.

George ORWELL, El poder y la palabra, selección y prólogo a cargo de Miguel BERGA, Madrid: Debate, 2017.

Javier PAMPARACUATRO, "En torno a la crisis del Derecho", Revista de Derecho Politico, núm. 92, 2015, pp. 165-194.

Juli PONCE, "Inteligencia artificial, Derecho administrativo y reserva de humanidad: algoritmos y procedimiento administrativo debido tecnológico", Revista General de Derecho Administrativo, núm. 50, 2019.

Jesús PRIETO DE PEDRO: Lenguas, lenguaje y derecho, Madrid: Civitas, 1991.

"Lenguaje jurídico y Estado de Derecho", Revista de Administración Pública, núm. 140, 1996, pp. 111129. 
"L'innovazione linguistica nella legislazione amministrativa", en Daniele MARONGIU y Isaac MARTÍN DELGADO (dirs.), Diritto amministrativo e innovazione. Scritti in ricordo di Luis Ortega, Napoli: Edizione Scientifiche Italiane, 2016, pp. 133-140.

Esther RANGO, "Los escritos de preparación e interposición del recurso de casación: requisitos y consecuencias jurídicas de su inobservancia", Revista General de Derecho Administrativo, núm. 51, 2019.

Gregorio ROBLES, El derecho como texto. Cuatro estudios de teoría comunicacional del Derecho, 2. ${ }^{\mathrm{a}}$ ed., Madrid: Cuadernos Civitas, 2006.

—La justicia en los juegos. Dos ensayos de teoría comunicacional del derecho, Madrid: Trotta, 2009, pp. 49 a 94.

—-Introducción”, en Diego MEDINA (coord.), La teoría comunicacional del derecho a examen, Madrid: Civitas-Thomson Reuters, 2017, pp. 11- 21.

Orlando ROSELLI, "Il Diritto come linguaggio. Riflessioni sulle trasformazioni del linguaggio e delle funzioni del Diritto", Culture and Language; Legal Language Metamorphosis, vol. 6, 2013 disponible en http://www.lawandliterature.org/index.php?channel=PAPERS.

Fernando SAINZ MORENO, Conceptos juridicos, interpretación y discrecionalidad administrativa, Madrid: Madrid, 1976

— "Los textos normativos. Condiciones de inteligibilidad", ob. col. Actualidad y perspectivas del derecho público a fines del siglo XX: Homenaje al profesor Garrido Falla, tomo I, Madrid: Editorial Complutense, 1992, pp. 441-471.

— "Problemas actuales de la técnica normativa", Anuario Jurídico de La Rioja, núm. 1, 1995, pp. 55-70.

Gregorio SALVADOR, "La lengua y el derecho. La percepción del filólogo", en Aurelio MENÉNDEZ (dir.), La proliferación legislativa: un desafio para el Estado de Derecho, Madrid: Thomson Civitas, 2004, pp. 631-641.

Jesús SÁNCHEZ LOBATO (coord.), Saber escribir, Madrid: Instituto Cervantes y Santillana Ediciones Generales, 2006.

John SEARLE, Speech Acts: An Essay in the Philosophy of Language, Cambridge: Cambridge University Press, 1969. Citamos por la traducción al español de Luis VALDÉS, Actos de habla. Ensayo de filosofía del lenguaje, Madrid: Cátedra, 1994.

Richard K. SHERWIN, Visualizing Law in the Age of the Digital Baroque, New York: Routledge, 2011.

- "Introduction: Law, Culture and Visual Studies", en Anne WAGNER y Richard K. SHERWIN (eds.), Law, Culture and Visual Studies, Springer Verlag, 2014, pp. xxxiii-xvi.

George STEINER, Les Logocrates, L'Herne, 2003. Citamos por la edición en español Los logócratas, Madrid: Siruela, 2006.

Ingemar STRANDVIK, "La modernización del lenguaje jurídico en Suecia: ‘enseñanzas aplicables a otras tradiciones?", en Estrella MONTOLÍO (ed.), Hacia la modernización del discurso jurídico, Barcelona, Universidad de Barcelona, 2012, pp. 131-149.

Cass SUNSTEIN, Why Nudge?: The Politics of Libertarian Paternalism, Yale University Press, 2015. Citamos por la edición en español Paternalismo libertario. ¿Por qué un empujoncito?, Pensamiento Herder, 2017.

Raquel TARANILLA e Irene YÚFERA, "Historias y argumentos. Operaciones textuales para narrar y argumentar en los textos judiciales", en Estrella MONTOLÍO (ed.), Hacia la modernización del discurso jurídico, Barcelona: Universidad de Barcelona, 2012, pp. 161-178.

Raquel TARANILLA, "El empleo de imágenes en la sentencia judicial. Reflexiones sobre la evolución del género", Revista Llengua i Dret, núm. 63, 2015, 1-12.

José Juan TOHARIA, "Las profesiones jurídicas: una aproximación sociológica”, en Luis Ma DÍEZ-PICAZO (coord.), El oficio de jurista, Madrid: Siglo XXI de España Editores, Madrid, 2006, pp. 1-16.

José TORRES, Lingüistica procesal. Estrategias discursivas en los juicios españoles, Bosch: Barcelona, 2017.

Bert VAN ROERMUND, Derecho, relato y realidad, Madrid: Tecnos, 1997.

Luciano VANDELLI, Papeles y papeleo. Burocracia y literatura, Madrid: Ediciones El Cronista, 2015.

Marcos VAQUER, "La formación de conceptos en el Derecho público: un comentario", Revista Vasca de Administración Pública, núm. especial 99-100, 2014, pp. 3005 a 3023.

Luis VERES, La retórica del terror. Sobre lenguaje, terrorismo y medios de comunicación, 2. a ed., Madrid: Ediciones de la Torre, 2006. 
Fernando VILCHES y Ramón SARMIENTO, Lenguaje juridico-administrativo. Una lengua de especialidad, Madrid: Dykinson, 2016.

Evelina WILL,"Bernhard Schlink, Ein Leben zwischen Prosa und Jurisprudenz", Freilaw. Freiburg Law Students Journal, núm. 1, 2015, pp. 61-62.

Virgilio ZAPATERO, "Estudio preliminar" a Jeremy BENTHAM, Nomografía o el arte de redactar leyes, Madrid: BOE y CEPC, 2004. 